\title{
Self-reporting traffic crashes - a systematic literature review
}

\author{
Noor Azreena Kamaluddin ${ }^{1,2^{*}}$ (D, Camilla Sloth Andersen ${ }^{3}$, Mette Kathrine Larsen ${ }^{4}$, Katrine Rabjerg Meltofte ${ }^{4}$ \\ and András Várhelyi ${ }^{1}$
}

\begin{abstract}
Purpose: A traffic safety analysis that is based on registered crashes often suffers from underreporting, which may result in biased conclusions and lead to misguided crash-prevention strategies. Self-reporting traffic crashes is a complementary method to obtain crash information that is often not available in official databases. By surveying studies from around the world, this paper aims to map the current practices in the collection of data from self-reporting traffic crashes.
\end{abstract}

Method: A systematic literature search was carried out in three databases, ScienceDirect, Scopus and Transport Research International Documentation (TRID), resulting in 134 reviewed studies.

Results: Self-reported crash studies were found to be more common in Europe, North America and Australasia, but there are few studies in developing countries. The reviewed studies mostly focused on adult road users (i.e. legal age of obtaining driving license and with no upper limit) and car users. Questionnaires (either paper based or online) were the most often used method, and 1 year was the most common recall period used. Regardless of its drawbacks, the reviewed studies showed that researchers 'trust' self-reports.

Conclusion: More studies should be conducted, especially targeting adolescent and young adults (age of 15-30 years) and vulnerable road users (VRUs). Developing countries should increase their efforts when it comes to using self-reporting to better assess the actual traffic safety situation and produce knowledge-based appropriate safety measures. Utilisation of smartphone application to assist data collection in self-reporting study for in-depth crash analysis should be explored further.

Keywords: Traffic safety, Traffic crash, Self-reporting, Road user, Review

\section{Background}

Today, traffic safety work is based on registered crashes with the goal of addressing the problems identified in crash data analysis such as to reduce number and severity of injuries. However, inaccurate traffic crash records may bias the results of traffic safety analyses, consequently leading to misguided crash-prevention strategies. A major problem concerning the availability of accurate information about traffic crashes is the incomplete crash records in the official statistics [1]. Recorded crashes involving vulnerable road users (VRUs; e.g., pedestrian, cyclist and motorcyclist) are underrepresented in the official national statistics, especially those involving slight injuries (see, e.g., [2-6]). Because, on average, road traffic

\footnotetext{
* Correspondence: azreena.kamaluddin@outlook.com

'Department of Technology and Society, Lund University, P.O. Box 118, John Ericssons väg 1, SE-22100 Lund, Sweden

${ }^{2}$ Faculty of Civil Engineering, Universiti Teknologi MARA, 40450 Shah Alam, Malaysia

Full list of author information is available at the end of the article
}

deaths worldwide involve vulnerable road users, with approximately $50 \%$ in high-income countries, $60 \%$ in middle-income countries and 70\% in low-income countries of all registered crashes [7], complementary data about the injury situation of these groups are of great value, giving the opportunity to extend the scope of data available for research and safety improvement measures.

Traffic crash cases are documented by police, and injured or killed persons are noted by hospital registers. Both registers suffer from underreporting (see, e.g., [8-10]). Insurance companies also collect crash data, but usually, these data are not accessible for actors outside the company. Various factors may affect the reporting of crash events such as injury severity, day and time of crashes, demographic characteristics (e.g., age group and gender) and cost of damages (discussed in [11]). The incompleteness of traffic crash records is a worldwide issue, both in developed countries (see, e.g., $[3,9])$ and developing countries (see, e.g., $[11,12])$, which 
has led researchers to call for complementary sources of information on road traffic crashes.

Other than being documented by the police, hospital, insurance companies or other records (e.g., a company record), some unrecorded traffic crashes can be traced via self-reports. Self-reporting is a common way to address underreporting problems as a complementary approach to official records (see, e.g., [13-15]). Self-reports are widely used in research areas such as transportation research, social science and medicine, here finding a role as a complementary approach to obtain more individual information. Since self-reports of traffic crashes provide useful complementary information to official reports, they are of great value, and are increasingly used in low- and middle-income countries [16]; it is an individual reporting system that divulges the participant's information not recorded in any official documents without researcher interference. The participants normally are asked to report their personal information without any external influences. Lajunen and Özkan [17] claimed that self-report surveys are a cost-effective and easy way to gather large samples of data. However, Violanti and Marshall [18] stated that self-reported crashes usually are more numerous than those found in the official records because most drivers usually report more crashes than the official files contain [19].

Self-reporting can have many different aims depending on the research question being investigated, but there are various issues of importance, such as study design (e.g., type of questionnaire/interview to be used for data collection, recruitment of respondents, sample size, recall period, type of crashes and type of road users), the reliability and validity of the data and reporting bias (i.e., recall - possibility of overreporting or underreporting and social desirability). The ways of getting information from people can vary; they may be asked to fill out written questionnaires (either online or paper based), participate in interviews (either face-to-face or via telephone) or report their crash involvement via an app on their mobile device. Also, response rates might vary depending on the data collection method. Some study designs may necessitate follow-up sessions to obtain possible additional information. The target group may be some specific group of road users, e.g., car users, bicyclists or pedestrians, a certain age group or people with a certain illness and participant selection may be voluntarily or random. The sample size may vary with the purpose of the study or simply be limited by economic considerations. The information that people are asked to give also may vary. In some studies, only the number of crashes in which the respondent was involved may be of interest. In other studies, respondents may be asked about possible crash contributory factors, and some studies deal with the respondent's recollection of the crash details. A sensitive issue is the anonymity of the respondents. If self-reports to be compared to other sources of traffic crash records, e.g., hospital or police records, an individual identifier is necessary to be able to match crash events in both data sources and in this case a consent given by the respondent is needed. Finally, but not least, the added value of self-reporting studies in their context is of relevance. A good insight in these issues and how they influence the outcome of a self-reporting study is of interest for those working with road safety analysis based on crash data.

\section{Aim}

The present review article aims to map the current practice in the collection of road traffic crash data by surveying studies where traffic crashes were reported by the involved road users. The analysis is focused on the publications that emphasise the methodological aspects, such as selection and type of respondents, sample size, data collection method and so forth. Advantages and drawbacks of the various ways to carry out a self-reported study are discussed and recommendations for further studies are given.

To the best of our knowledge, there is no published literature review paper about the processes surrounding the issue of self-reporting of traffic crashes in transportation literature.

\section{Method}

A systematic literature review was carried out to map the current practice of data collection for self-reported traffic crashes. Three databases were searched for publications: ScienceDirect, Scopus and Transport Research International Documentation (TRID). ScienceDirect contains research articles from 3800 journals and more than 37,000 book titles. Scopus is the largest abstract and citation database (i.e., journals, books and conference proceedings), and it contains more than 22,800 serial titles and more than 150,000 books that come from more than 5000 publishers. Both ScienceDirect and Scopus are owned by Elsevier. TRID focuses on transportation research and contains more than 1.1 million records worldwide (i.e., books, technical reports, conference proceedings and journal articles) and is maintained by the Transportation Research Board of the U.S. National Academies. A search of these three databases is expected to cover all relevant publications in the transport research area.

\subsection{Search strategy}

Combinations of three groups of keywords, strings (*) and Boolean operators (AND/OR) were used in the search strategy to retrieve the relevant publications (see Table 1). The 'AND' Boolean operator was used to connect keyword groups while the 'OR' Boolean operator was used to connect each keyword in the groups. All keywords were searched in the title, abstract and keywords sections in each database.

The systematic literature review aimed to locate publications related to the self-reporting of traffic crashes. Because the words 'accident' and 'crash' are used as synonyms for each other in academic publications, both were used in the 
Table 1 Search terms and keywords used in the literature search

\begin{tabular}{lll}
\hline First keyword & Second keyword & Third keyword \\
\hline Accident* OR Crash* & Self-report* OR Selfreport* & Traffic* OR \\
& Car* OR \\
& Pedestrian* OR \\
& Bus* OR \\
& Truck* OR \\
& Lorry* OR \\
& Moped* OR \\
& Scooter* OR \\
& Motorcycle* OR \\
& Taxi* OR \\
& Bicyclist* OR \\
& Vulnerable Road User* \\
\end{tabular}

search strategy as the first keyword. The second keyword was used to specify the method of data collection, here being self-reporting by the road users. The third keyword was crucial for retrieving the most relevant publications in the transport research field because the word 'accident' (first keyword) also covers broad areas of research; hence, it will return a very high number of hits, where the majority are related to other kinds of accidents (e.g., industrial accidents), not just traffic accidents. 'Self-reporting' (the second keyword) is also used in various fields of research, including medicine and social science.

Publications written in English were included, except for the ScienceDirect database, where no language filter tool was available. Therefore, non-English retrieved publications from ScienceDirect were manually excluded. The search was limited to the last 11 years (2006-October 2017). The titles and abstracts were screened according to the following inclusion criteria:

i. The paper deals with traffic crashes/accidents.

ii. Self-reporting means that people provide information on at least the number of crashes but perhaps also more details, either via face-to-face interviews, telephone interviews, questionnaire (paper or online) or by other means.

A codebook was established to thoroughly review the publications that met the above criteria. Using a codebook helps the reviewer extract the important themes and findings of the studies and expedite the analysis stage. The codebook classified information on several aspects, including publication ID, full reference, link to publication, year of publication, language of the publication, non-inclusion criteria in the case where a paper was not included, focus of the study (either methodological, practical applied or both), how the data were collected, sample size, the recruitment of the respondents, age group of the respondents, road user type, the recall period and interval the respondent was asked to self-report, follow-up frequency, response rate, whether the self-reported data were compared with crash data that were registered by other means, the country the study was conducted in and what the self-reported crash data were used for. Figure 1 shows a conceptual model of the issues considered in study design, which constitute the basis of the outcomes of the current self-reporting study. For example, the data collection method and recruitment method that ensures the anonymity of the respondents will influence the response rate, but it also could increase or decrease the desirability bias.

There were 1533 hits in the selected databases (i.e., ScienceDirect $=148 ;$ Scopus $=542 ;$ TRID $=843$ ). All retrieved publications were exported to EndNote X7.7.1 for a screening process. Two hundred and fifty-five duplicate publications were removed, resulting in 1278 to be thoroughly screened. Three non-English publications were removed. Two stages of the screening process were performed to remove irrelevant publications; the first screen was based on the title and abstract, and the second screen was based on the full text. At the end of the screening process, 127 publications were kept and included in the review. Three of the publications described more than one study of self-reporting traffic crashes, which in total gave 134 studies to be coded and discussed (See the table in Appendix).

\section{Findings}

The number of publications on self-reported traffic crashes has increased over the last 10 years, indicating that this area is relevant and useful in the transportation safety engineering field when it comes to assessing safety problems or crash causation factors.

\subsection{Focus of the studies}

The reviewed studies could have their focus either on methodological or applied/practical aspects. Of the 134 studies reviewed, two-thirds mainly had an applied/practical focus, getting accident data without emphasising the method used to obtain the data. Forty-one studies focused on both the practical/applied issues and methodological aspects of self-reporting of traffic crashes. Five studies had a strong methodological focus where the method was explained in detail [20-24].

Various motivations were found to drive the studies on self-reporting of traffic crashes, such as safety evaluation [21, 23-68], investigation of crash causation factors [22, 69103], determination of the number of crashes for a specific group (e.g., novice drivers, elderly) [104-131], estimation of underreporting [15, 20, 132-139], calculation of crash costs [140] or other factors (e.g., to investigate the memory effect) [141-145]. However, all studies were conducted at the very least to understand and assess the traffic safety situation.

\subsection{Studies by world regions}

Self-reporting studies were mainly conducted in European, Australasian and North American countries (see Fig. 2). Fewer studies were conducted in Asian, African, South 


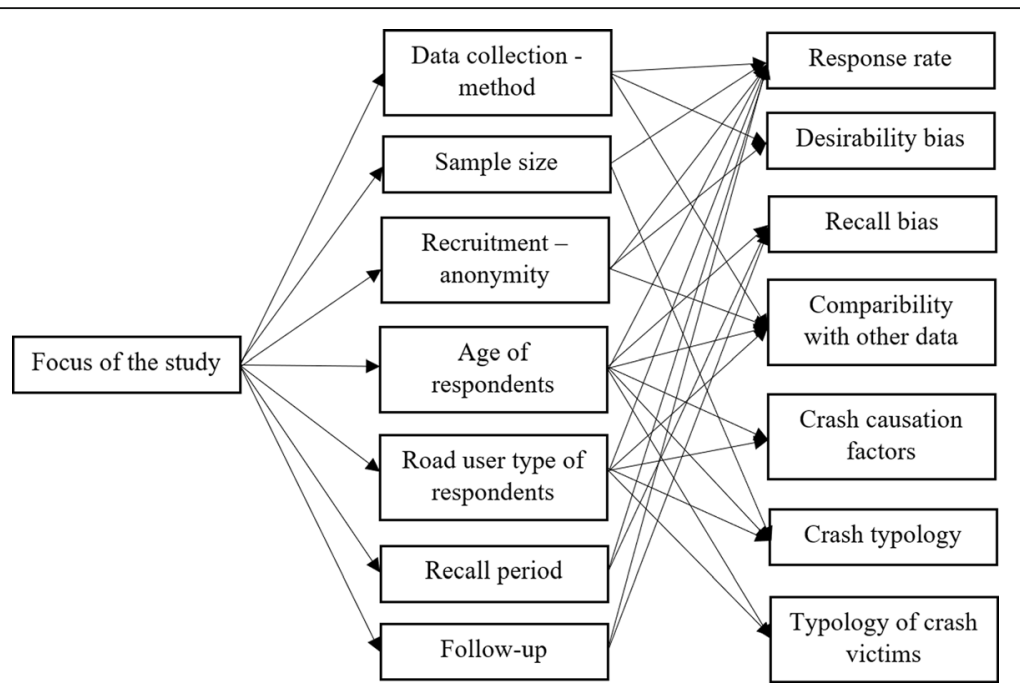

Fig. 1 The conceptual model used in the analysis of self-reporting studies

American and Middle Eastern countries. Three publications compared self-reporting studies from multiple regions (i.e 7 countries) (i.e., $[40,67,104])$. Eighty-two percent of the studies collected data from a limited area (town or region) while $16 \%$ of the studies covered a whole nation.

\subsection{Data collection}

The reviewed studies used various data collection approaches (see Fig. 3). The approach can be based on various criteria, for example, efficiency in recruiting potential respondents, assessed response rate, time-efficiency or the costs of conducting the study. Using a questionnaire was found to be the most frequent method used for data collection, either online or paper. Interviews seemed to be a less popular method of data collection. Twenty-nine of the reviewed studies conducted follow-up sessions to obtain information on possible additional crashes that might have occurred after the preceding session (e.g., weekly, fortnightly, monthly, every 3 or 6 months, annually) [20, 23, 24, 38, $40,41,45,47,52,55-57,63,67,77,83,87,111,116$, $121,129,133-136,138,144,145]$. Interestingly, there is one unique study used smartphone sensors to assist with data collection [108]. Not all reviewed studies stated the response rate of the respondents (see Appendix).

Most of the studies selected the target group of road users either voluntarily or randomly; some specific group of road users, such as people with a certain illness (see, e.g., $[115,131]$ ), young adults (see, e.g., [27]) or elderly (see, e.g., [134]). Figure 4 shows the basis for recruiting respondents in the reviewed studies.

There was a large amount of variation in the type of road users targeted in the reviewed studies (see Fig. 5). Almost half of the studies targeted car users as the study's

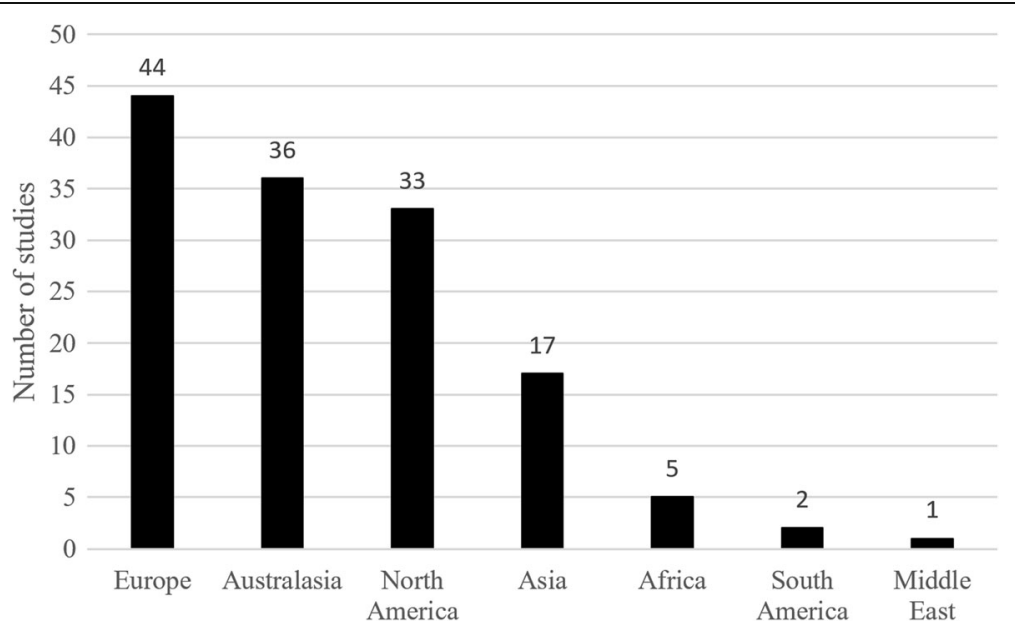

Fig. 2 Distribution of the studies by world regions (three of the studies were made in multiple regions) 


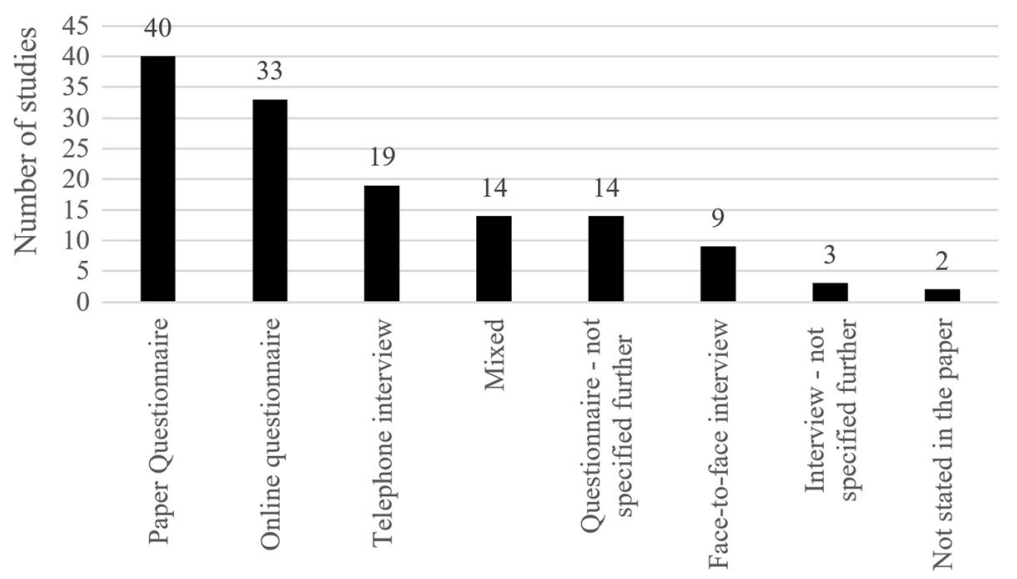

Fig. 3 Method of data collection

respondents. Only a few studies focused on VRUs, despite these groups of road users having the highest number of casualties and being the most underreported $[3,6,12,146]$. Bicycle safety studies seem to have become popular recently and mostly are found in Australasia and European countries and Canada. Some of the studies combined all types of road users or more than one type of road user (see, e.g., $[75,88]$ ).

The size of sample in the reviewed studies ranged from less than 100 to more than 10,000, depending on the objective of the study (see Fig. 6).

The reviewed studies also varied regarding the age group of the recruited respondents. Sixty-three percent of the studies focused on adults, covering those older than the legal age of obtaining a driver's license and with no upper limit, while the rest included respondents ranging from children to elderly. Three studies involved respondents who were aged 16 years and older [54, 69, 107].
Only $16 \%$ of the reviewed studies focused on young adults of 15-30 years old (details in Appendix).

The recall periods used by the reviewed studies varied from less than a month to up to more than 5 years or since licensure. Approximately $60 \%$ of the recall periods ranged 1-3 years, with most of them being 1 year (50 studies). Only about $11 \%$ of the reviewed studies used lifetime or more than 5 years of a recall period.

One quarter of the studies compared self-reports to other sources of traffic crash records, such as hospital records, police records, insurance records, company records, multiple records or other data sources. These types of comparisons were possible only if consent had been given by the respondents and if permission was granted by the authority (e.g., police) to access individual data in the crash database. Ethical approval had to be obtained if the conducted research involved confidential data especially from medical records.

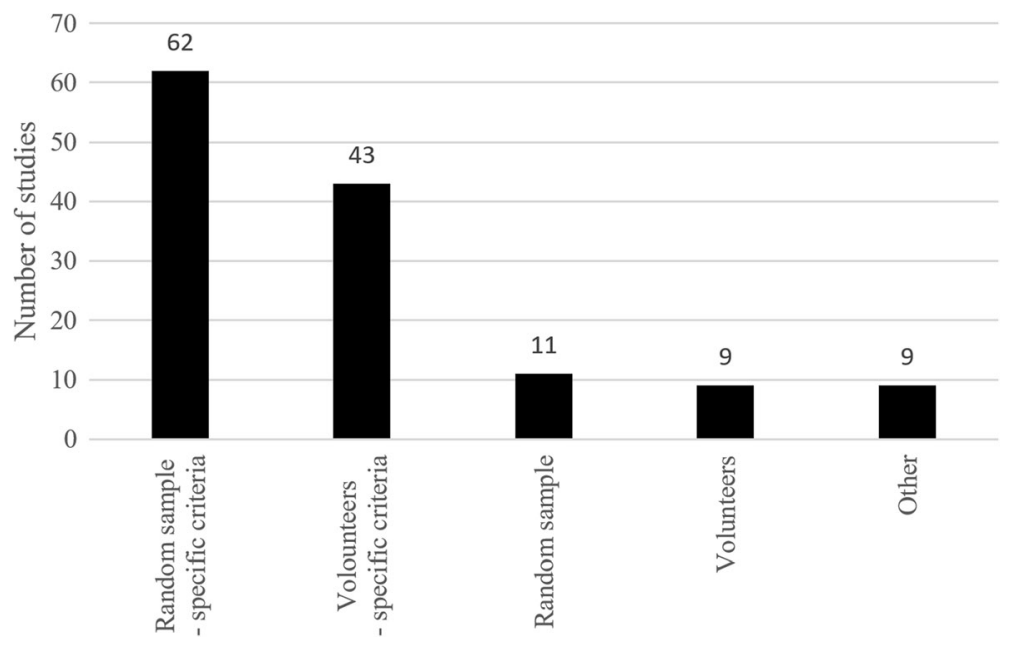

Fig. 4 Basis for selection of respondents (details in Appendix) 


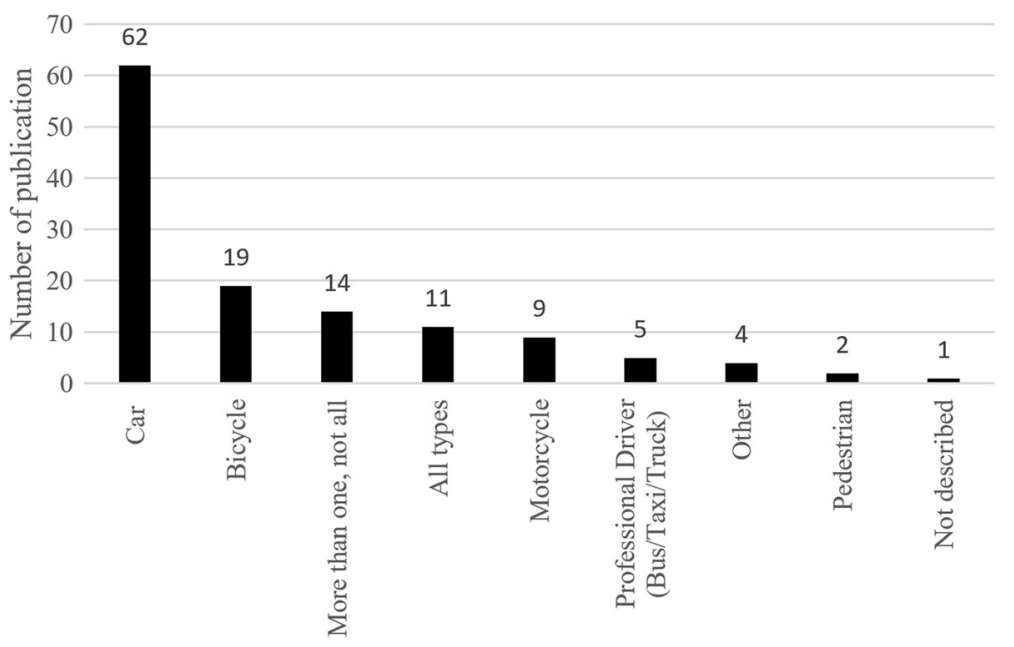

Fig. 5 Type of road users involved in the traffic crashes

\section{Discussion}

This review focused on the self-reporting of traffic crashes in a traffic safety engineering context. A well-constructed search strategy was essential to find all relevant publications.

In general, the studies reviewed in the current paper mainly focused on car crashes (49\%) and involved adult road users (63\%). Fewer studies targeted VRUs (24\%), despite the fact that traffic crashes are the main cause of death among those aged $15-29$ years and that almost $50 \%$ of all deaths on the world's roads occur among those with the least protection, such as pedestrians, cyclists and motorcyclists [7].

The majority $(82 \%)$ of the studies reviewed were conducted in Europe, North America and Australasia and had a practical and/or applied focus (65\%). Fewer studies (18\%) were conducted in Asian, South American, African and Middle Eastern countries. Knowing that official crash data are not always available to the researcher and road authorities in developing countries (see, e.g., [11]), developing countries would benefit from using the self-reporting approach to conduct road safety studies so that the real safety situation of the country could be appropriately assessed to determine the crash causation factors, estimate underreporting, crash costs and reveal other effects (e.g., psychological distress after injury as studied by Tran et al. [145]), and consequently improve their traffic situations. A WHO [7] reported, most of the traffic deaths (approximately 90\%) occur in developing countries, where rapid economic growth in parallel with motorisation has led to traffic injuries, especially those involving VRUs (60-70\%). Also, Mock et al. [16] recommended that self-reporting would be a suitable approach in low- and middle-income countries due under-reported in the official records.

Apparently, most of the researchers were aware of the 'social desirability' bias that is sometimes present in self-reporting studies (as argued by [40]) and incorrect memory recall due to passage of time from crash event occurred to when the respondent was asked to recall it $[16,147]$ because most of the reviewed studies discussed these issues.

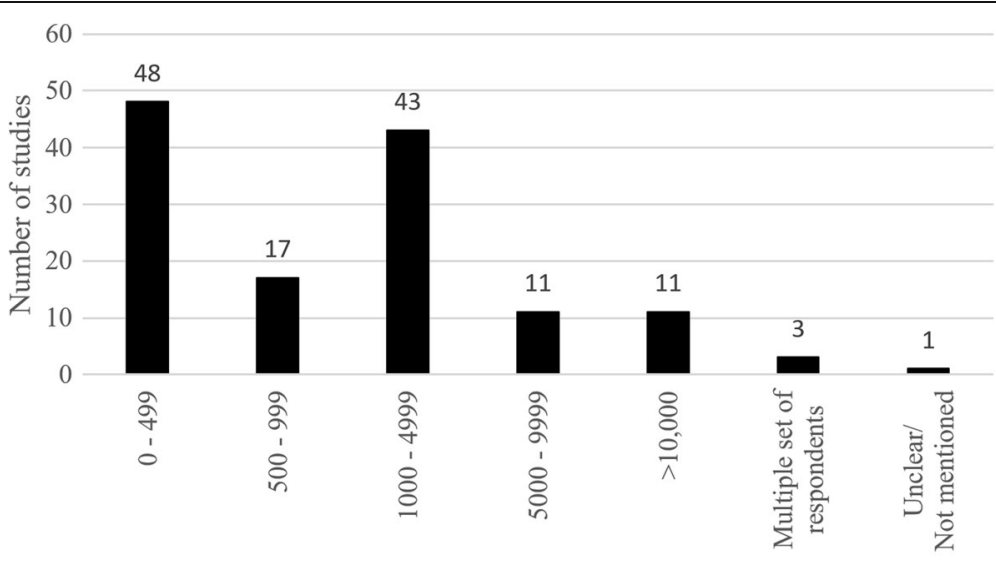

Number of respondents

Fig. 6 Sample sizes of the reviewed studies 
A social desirability bias may occur when the respondents want to show that they are good road users, which could affect the number of reported crashes. The possibility of this bias being present could increase if the respondents' personal information is asked for. A social desirability bias could be prevented by applying anonymous questionnaires if the reported crashes are not going to be linked to other data sources. Then, a personal identifier is not important. However, in this case, the self-reporting data cannot be validated.

Another issues in self-reporting is the deterioration of memories, which could arise because of several factors, such as the seriousness of the experienced crash, the number of involved vehicles and how long ago the crash had occurred. The deterioration of a respondent's memories may significantly affect the reliability of self-reporting data. af Wåhlberg et al. [40] claimed that drivers do not report their involvement in crashes accurately (overreporting or underreporting), while a study conducted by Bajaj et al. [20] found a strong agreement (90\%) between the self-reports of traffic crashes for cirrhosis patients and the official records. af Wåhlberg et al. [40] suggested that self-reports should be used in parallel with a lie scale to control for the possible lie effect. Nevertheless, none of the 134 studies reviewed incorporated a lie scale. Incorrectly recalling one's involvement in a traffic crash can only be addressed with a shorter recall period or a regular reporting scheme. Long recall periods carry the risk of forgotten crash events that may amount to approximately 30\% each year [147]. Therefore, some of the reviewed studies used regular follow-up sessions, driving diaries or limited recall periods to reduce the effect of memory recall bias. Based on the findings, it seems that a maximum of 1 year is the optimal recall period: the time period is short enough to reduce the risk of recall bias, but it is still a long enough to allow for the collection of a satisfactory amount of data.

Obviously, researchers 'trust' self-reports, which is indicated by the increasing number of publications using self-reporting as a research method for data collection, despite the reliability and validity issues and possibility of reporting bias that come with self-reported data. Of the reviewed studies, 48 used self-reports to assess the safety situation, 39 to identify crash causation factors, 31 to determine the number of crashes for a specific group, 10 to estimate underreporting, five to solve other issues related to traffic safety and one to estimate the costs of crashes. For example, a study conducted by Finestone et al. [52] that evaluated safety among stroke survivors showed that self-reports are useful in complementing the official records because some of the crashes are not reported in the official records but are registered in self-reports and vice-versa; therefore, a combination of both records could give a more accurate picture of driving safety. Hassan and Abdel-Aty [91] used the results of self-reports to suggest crash risk-reduction measures and to promote safe driving among young drivers.
Using a questionnaire (either paper or online) was the most frequent approach for collecting self-reported data. Some of the studies used both types of questionnaires to reach the targeted respondents because not all the respondents had Internet access. Interviews (either telephone or face-to-face) seemed to be less popular (23\%). Nevertheless, interviews logically could reduce the number of outlier respondents because the interviewer could ask or rephrase the questions to ensure that the respondents understand the questions. There were several studies using telephone interviews as a follow-up to obtain more information about the reported crashes $[111,134]$. When dealing with young respondents (school children) for paper-based or online questionnaires, the researcher was always present.

The utilisation of a smartphone device seems to be a promising approach for collecting self-reported data and recorded data. More recent smartphones normally are embedded with sensors to trace movement and rotation. A study conducted by Isho et al. [108] used smartphone sensors to record trunk acceleration associated with fall risk among post-stroke elderly with and without fall history. They found that smartphone can provide detailed pattern of movement that might be useful as a complementary data to better understand the crash course of event. There are ongoing efforts to develop these types of sensor-based apps in a EU-project called InDeV (In-depth understanding of accident causation for vulnerable road users) [148]. However, more research is needed to investigate their stability, validity and reliability.

The quality of self-reports strongly depends on the way the questions are asked in connection with the reason for asking the question. The approach used for a self-reporting study is influenced by the expected number of respondents and expected response rate. The number of recruited respondents depends on the objective(s) of the study (if focused on a limited area, a whole nation or a specific group of road users). The expected response rate, however, did not seem to be a robust indicator for deciding the best practice of data collection because not all the reviewed studies stated the figure and depended on how the questionnaires were distributed or the interviews were conducted; sometimes, the studies did not account for the number of total invitations. The response rate was provided in some papers, and in some others, it could be manually calculated. The reported response rate was anywhere between $1 \%$ and $100 \%$, and not robust to be relied on to drawn conclusion of the self-reports; however, for 56 of the studies, no response rate was available. A combination of several methods could also improve the quality of the study and could produce a higher response rate $(>80 \%)$ (see, e.g., $[65,140])$. It should be noted that a paper-based questionnaire is costly compared with an online questionnaire. Nevertheless, several aspects should be considered when using online questionnaires, such as the 
availability of a server to host the questionnaire and the Internet access for the targeted respondents. Interviews seem to be a promising approach, but they are also costly (e.g., transportation costs for face-to-face interviews or the costs for telephone interviews), and it is very time-consuming if involving a large number of respondents.

The reviewed studies often targeted respondents using specific criteria, recruiting either volunteers or selecting them randomly from a specific type of target group (e.g., school children, novice drivers, offending drivers, etc.). Respondents were invited and recruited at public service areas (e.g., train station, gas station, etc.), at shopping centres or by advertising on social media, websites, e-mail, flyers and word of mouth. Also, participants of events were targeted (e.g., bicycle event) for a limited study region (see, e.g., [50, 136]). To represent young drivers, most of the studies targeted high school students, university students and driving license learners (see, e.g., $[28,55,79,137])$. A random recruitment of citizens was usually used to collect the data representative for an entire nation, for example, in Goldenbeld et al. [22]. Some studies divided the study area into several geographical units, for example, Gliklich et al. [95], and limited the number of respondents in each area by making the sample stratified. Epidemiological studies usually targeted hospital patients to obtain the patients' crash history, which could be related to their health status development (see, e.g., [20, 52, 69]).

The current review is limited to the studies retrieved from the selected databases, and there is a possibility that self-reporting traffic crash studies published elsewhere are not included here. The database search was restricted to only English language literature published from the year 2006 until October 2017 and that was available online. Due to the language barrier, it can be expected that some of the research articles written by researchers in Asian, South American, African and Middle Eastern countries were locally published and not indexed in the mainstream international databases, affecting the number of available publications from these countries. Some of the publications focused on driver behaviour by employing a 'Driver Behaviour Questionnaire' were excluded, even if a question asked for the number of crashes the participant was involved in.

\section{Conclusions and recommendations}

Self-reporting is a useful tool that can be used as a complementary method to obtain more information on crash events, but reliability and validity issues should always be taken into consideration. The following conclusions can be drawn from this review:

- Studies of self-reported crashes are more common in European, North American and Australasia countries, but there are few in developing countries.
- Most of the reviewed studies were conducted on car users. Studies on VRUs (i.e., pedestrians, cyclists, motorcyclists, etc.) were relatively few.

- A questionnaire (either paper or online) approach was more common than interviews (either face-toface or telephone), but a combination of more than one approach could reach more potential respondents and produce a better response rate.

- A recall period of 1 year was the most common in the reviewed studies, though it ranged from less than a month to more than 5 years.

Because official crash databases are far from complete and the VRUs involved in traffic crashes are overrepresented, self-reporting studies of traffic crashes of VRUs should be conducted to complement the official files.

More studies should be conducted to assess the safety of younger populations ( $<30$ years) because this group of road users are overrepresented in traffic crashes. Developing countries should increase their efforts in this area to efficiently assess the actual traffic safety situation.

Crashes recorded in the self-reports could be linked to official databases to determine the degree of agreement and increase the data validity. Not to mention, a sufficient individual identifier is required to match crash events in both data sources [149]. Nevertheless, consent from the individual respondents should be granted prior to a data link is performed. The possibility that respondents, aware that their self-reported data will be linked to official crash records, will only recall crashes that had been reported to the official files, thus resulting in an underreporting of crashes, should be considered. However, because including an individual identifier could lead to a social desirability bias, anonymity issues should be taken into account, as suggested by Lajunen and Özkan [17].

It is important for researchers to be aware of the shortcomings (i.e. reporting bias - social desirability and incorrect memory recall) of self-reporting and take the appropriate measures to mitigate them. Studies emphasising the method used should be made to promote an in-depth understanding of self-reporting traffic crashes. Furthermore, research papers should be more explicit in explaining the method of self-reporting by clearly stating how the data collection was conducted, how the targeted respondents were approached, the total number of respondents, the response rate, the recall period used and which category of road users (i.e., age and type) were included in the study.

Traffic safety research could benefit from the rapidly growing of smartphone devices with their sophisticated technology. Use of smartphone applications can assist data collection for in-depth crash analysis. Crash detection via smartphone app, particularly involving VRUs, is to be explored further. 


\section{Appendix}

Table 2 Summary of the studies reviewed based on method

\begin{tabular}{|c|c|c|c|c|c|c|c|c|}
\hline Num. & Publication & Recall period & $\begin{array}{l}\text { Selection of } \\
\text { respondents }\end{array}$ & $\begin{array}{l}\text { Number of } \\
\text { respondents }\end{array}$ & $\begin{array}{l}\text { Response rate } \\
(\%)\end{array}$ & $\begin{array}{l}\text { Type of road user / } \\
\text { crashes }\end{array}$ & Age-group & $\begin{array}{l}\text { Link to other } \\
\text { database? }\end{array}$ \\
\hline \multicolumn{9}{|c|}{ Paper Questionnaire } \\
\hline 1 & $\begin{array}{l}\text { Aduen et al. } \\
\text { [115] }\end{array}$ & $1-3$ years & $\begin{array}{l}\text { Random } \\
\text { sample }\end{array}$ & 3259 & 90 & Car & Adults $^{a}$ & Yes, other \\
\hline 2 & $\begin{array}{l}\text { af Wåhlberg } \\
\text { [144] }\end{array}$ & $\begin{array}{l}3 \text { months- } \\
1 \text { year }\end{array}$ & $\begin{array}{l}\text { Random sample - } \\
\text { specific criteriab }^{\text {a }}\end{array}$ & 9969 & $\mathrm{n} / \mathrm{a}$ & Car & Adults $^{\mathrm{a}}$ & No \\
\hline 3 & $\begin{array}{l}\text { Álvarez et al. } \\
\text { [116] }\end{array}$ & $1-3$ years & $\begin{array}{l}\text { Volunteers - Specific } \\
\text { criteriab }^{b}\end{array}$ & 53 & 100 & All types & Adults $^{\mathrm{a}}$ & Yes, other \\
\hline 4 & $\begin{array}{l}\text { Bagdadi and } \\
\text { Várhelyi [76] }\end{array}$ & $1-3$ years & Volunteers & 166 & 100 & Car & Adults $^{\mathrm{a}}$ & Yes, other \\
\hline 5 & Bajaj et al. [20] & $1-3$ years & Other & 120 & 72 & Car & Adults $^{\mathrm{a}}$ & Yes, other \\
\hline 6 & $\begin{array}{l}\text { Berecki-Gisolf } \\
\text { et al. [21] }\end{array}$ & $1-3$ years & $\begin{array}{l}\text { Volunteers - Specific } \\
\text { criteriab }^{\text {b }}\end{array}$ & 57,154 & 27 & $\begin{array}{l}\text { More than one } \\
\text { but not all } \\
\text { (car \& motorcycle) }\end{array}$ & Adults $^{\mathrm{a}}$ & No \\
\hline 7 & $\begin{array}{l}\text { Buckley and } \\
\text { Sheehan [82] }\end{array}$ & $1-3$ months & $\begin{array}{l}\text { Volunteers - Specific } \\
\text { criteriab }^{\text {b }}\end{array}$ & 934 & $\mathrm{n} / \mathrm{a}$ & Motorcycle & $\begin{array}{l}\text { Children and } \\
\text { youngsters }\end{array}$ & No \\
\hline 8 & $\begin{array}{l}\text { Chang and Yeh } \\
{[25]}\end{array}$ & $1-3$ years & $\begin{array}{l}\text { Random sample - } \\
\text { specific criteriab }^{\text {b }}\end{array}$ & 1451 & 24 & Motorcycle & Adults $^{\mathrm{a}}$ & No \\
\hline 9 & $\begin{array}{l}\text { Cheng and } \mathrm{Ng} \\
\text { [133] }\end{array}$ & $1-3$ years & $\begin{array}{l}\text { Volunteers - Specific } \\
\text { criteriab }^{b}\end{array}$ & 920 & $74-90 \%$ & Motorcycle & Adults $^{\mathrm{a}}$ & No \\
\hline 10 & $\begin{array}{l}\text { Dingli et al. } \\
\text { [88] }\end{array}$ & $1-3$ months & $\begin{array}{l}\text { Random sample - } \\
\text { specific criteriab }^{\text {b }}\end{array}$ & 427 & $\mathrm{n} / \mathrm{a}$ & All types & $\begin{array}{l}\text { Children and } \\
\text { youngsters }\end{array}$ & No \\
\hline 11 & Gras et al. [106] & $1-3$ years & $\begin{array}{l}\text { Volunteers - Specific } \\
\text { criteriab }^{\text {b }}\end{array}$ & 1452 & $\mathrm{n} / \mathrm{a}$ & $\begin{array}{l}\text { More than one } \\
\text { but not all } \\
\text { (car \& motorcycle) }\end{array}$ & $\begin{array}{l}\text { Other } \\
\text { (19-30 years) }\end{array}$ & No \\
\hline 12 & $\begin{array}{l}\text { Henriksson } \\
\text { et al. [127] }\end{array}$ & $1-3$ years & Random sample & 1362 & 65 & Car & Elderly & No \\
\hline 13 & $\begin{array}{l}\text { Horswill et al. } \\
\text { [26] }\end{array}$ & $3-5$ years & $\begin{array}{l}\text { Random sample - } \\
\text { specific criteriab }\end{array}$ & 271 & 11 & Car & Elderly & No \\
\hline 14 & $\begin{array}{l}\text { Ibrahim et al. } \\
\text { [27] }\end{array}$ & $\begin{array}{l}3 \text { months- } \\
1 \text { year }\end{array}$ & $\begin{array}{l}\text { Random sample - } \\
\text { specific criteriab }^{-}\end{array}$ & 1324 & 88 & Pedestrian & $\begin{array}{l}\text { Other } \\
\text { (18-24 years) }\end{array}$ & No \\
\hline 15 & $\begin{array}{l}\text { Isler and } \\
\text { Newland [96] }\end{array}$ & $1-3$ years & $\begin{array}{l}\text { Volunteers - Specific } \\
\text { criteriab }^{\text {b }}\end{array}$ & 160 & $\mathrm{n} / \mathrm{a}$ & Car & Adults $^{\mathrm{a}}$ & No \\
\hline 16 & $\begin{array}{l}\text { Jiménez-Mejías } \\
\text { et al. [28] }\end{array}$ & $\begin{array}{l}3 \text { months- } \\
1 \text { year }\end{array}$ & $\begin{array}{l}\text { Volunteers - Specific } \\
\text { criteriab }^{b}\end{array}$ & 1114 & $\mathrm{n} / \mathrm{a}$ & Car & $\begin{array}{l}\text { Other (University } \\
\text { students -young) }\end{array}$ & No \\
\hline 17 & $\begin{array}{l}\text { Koekemoer } \\
\text { et al. [29] }\end{array}$ & $\begin{array}{l}\text { More than } \\
5 \text { years }\end{array}$ & $\begin{array}{l}\text { Volunteers - Specific } \\
\text { criteriab }^{\text {b }}\end{array}$ & 536 & $\mathrm{n} / \mathrm{a}$ & Pedestrian & $\begin{array}{l}\text { Children and } \\
\text { youngsters }\end{array}$ & No \\
\hline 18 & $\begin{array}{l}\text { King and } \\
\text { Parker [71] }\end{array}$ & $\begin{array}{l}\text { More than } \\
5 \text { years }\end{array}$ & $\begin{array}{l}\text { Random sample - } \\
\text { specific criteriab }^{\text {b }}\end{array}$ & 171 & 86 & Car & Adults $^{a}$ & No \\
\hline 19 & $\begin{array}{l}\text { Korpinen and } \\
\text { Pääkkönen [72] }\end{array}$ & $1-3$ years & $\begin{array}{l}\text { Random sample - } \\
\text { specific criteriab }\end{array}$ & 6121 & 41 & All types & Adults $^{\mathrm{a}}$ & No \\
\hline 20 & $\begin{array}{l}\text { Laapotti et al. } \\
\text { [30] }\end{array}$ & $3-5$ years & $\begin{array}{l}\text { Random sample - } \\
\text { specific criteriab }\end{array}$ & 8434 & 48 & Car & Adults $^{\mathrm{a}}$ & No \\
\hline 21 & $\begin{array}{l}\text { Lafont et al. } \\
\text { [31] }\end{array}$ & $3-5$ years & $\begin{array}{l}\text { Random sample - } \\
\text { specific criteriab }^{2}\end{array}$ & 1051 & approx. 50 & Car & Elderly & No \\
\hline 22 & $\begin{array}{l}\text { Lucidi et al. } \\
\text { [109] }\end{array}$ & $1-3$ years & $\begin{array}{l}\text { Random sample - } \\
\text { specific criteriab }^{\text {b }}\end{array}$ & 1008 & $\mathrm{n} / \mathrm{a}$ & Car & $\begin{array}{l}\text { Other } \\
\text { (18-23 years) }\end{array}$ & No \\
\hline 23 & $\begin{array}{l}\text { Mamo et al. } \\
{[124]}\end{array}$ & $3-5$ years & $\begin{array}{l}\text { Random sample - } \\
\text { specific criteriab }^{b}\end{array}$ & 213 & 98 & Only taxi & Adults $^{a}$ & No \\
\hline 24 & Ma et al. [32] & $1-3$ years & $\begin{array}{l}\text { Volunteers - Specific } \\
\text { criteria }^{\text {b }}\end{array}$ & 248 & 71 & $\begin{array}{l}\text { Other } \\
\text { (taxi \& bus) }\end{array}$ & Adults $^{\mathrm{a}}$ & No \\
\hline 25 & $\begin{array}{l}\text { Nordfjærn et al. } \\
\text { [73] }\end{array}$ & $\begin{array}{l}\text { More than } \\
5 \text { years }\end{array}$ & $\begin{array}{l}\text { Random sample - } \\
\text { specific criteriab }^{\text {b }}\end{array}$ & 247 & 23 & Car & Adults $^{\mathrm{a}}$ & No \\
\hline
\end{tabular}


Table 2 Summary of the studies reviewed based on method (Continued)

\begin{tabular}{|c|c|c|c|c|c|c|c|c|}
\hline Num. & Publication & Recall period & $\begin{array}{l}\text { Selection of } \\
\text { respondents }\end{array}$ & $\begin{array}{l}\text { Number of } \\
\text { respondents }\end{array}$ & $\begin{array}{l}\text { Response rate } \\
(\%)\end{array}$ & $\begin{array}{l}\text { Type of road user / } \\
\text { crashes }\end{array}$ & Age-group & $\begin{array}{l}\text { Link to other } \\
\text { database? }\end{array}$ \\
\hline 26 & Ross et al. [131] & $\begin{array}{l}\text { More than } \\
5 \text { years }\end{array}$ & $\begin{array}{l}\text { Volunteers - Specific } \\
\text { criteriab }^{\text {b }}\end{array}$ & 106 & $\mathrm{n} / \mathrm{a}$ & Car & Adults $^{a}$ & No \\
\hline 27 & Pizza et al. [79] & $\begin{array}{l}\text { More than } \\
5 \text { years }\end{array}$ & $\begin{array}{l}\text { Volunteers - Specific } \\
\text { criteria }^{\mathrm{b}}\end{array}$ & 339 & $\mathrm{n} / \mathrm{a}$ & Car & $\begin{array}{l}\text { Children and } \\
\text { youngsters }\end{array}$ & No \\
\hline 28 & $\begin{array}{l}\text { Salminen et al. } \\
\text { [113] }\end{array}$ & $1-3$ years & $\begin{array}{l}\text { Random sample - } \\
\text { specific criteriab }\end{array}$ & 306 & $37-42$ & Bus & Adults $^{a}$ & $\begin{array}{l}\text { Yes, to } \\
\text { insurance } \\
\text { records }\end{array}$ \\
\hline 29 & $\begin{array}{l}\text { Schanke et al. } \\
\text { [33] }\end{array}$ & $\begin{array}{l}\text { More than } \\
5 \text { years }\end{array}$ & $\begin{array}{l}\text { Volunteers - Specific } \\
\text { criteriab }^{b}\end{array}$ & 93 & 74 & Car & $\begin{array}{l}\text { Other } \\
\text { (18-25 years) }\end{array}$ & Yes, other \\
\hline 30 & $\begin{array}{l}\text { Scott-Parker } \\
\text { et al. [34] }\end{array}$ & $1-3$ years & $\begin{array}{l}\text { Volunteers - Specific } \\
\text { criteriab }^{b}\end{array}$ & 1076 & $n / a$ & Car & $\begin{array}{l}\text { Other } \\
\text { (18-20 years) }\end{array}$ & No \\
\hline 31 & Sirin et al. [35] & $\begin{array}{l}\text { Other (during } \\
\text { pregnancy) }\end{array}$ & $\begin{array}{l}\text { Random sample - } \\
\text { specific criteriab }^{\text {b }}\end{array}$ & 37,081 & 70 & Car & Adults $^{\mathrm{a}}$ & No \\
\hline 32 & $\begin{array}{l}\text { Stephan et al. } \\
\text { [36] }\end{array}$ & $1-3$ years & $\begin{array}{l}\text { Volunteers - Specific } \\
\text { criteria }^{\mathrm{b}}\end{array}$ & 87,134 & 44 & All types & Adults $^{\mathrm{a}}$ & No \\
\hline 33 & Tetali et al. [37] & $1-3$ years & $\begin{array}{l}\text { Random sample - } \\
\text { specific criteriab }^{\text {b }}\end{array}$ & 5789 & 99 & All types & $\begin{array}{l}\text { Children and } \\
\text { youngsters }\end{array}$ & No \\
\hline 34 & Tran et al. [145] & $1-3$ years & Volunteers & 42,785 & $\mathrm{n} / \mathrm{a}$ & $\begin{array}{l}\text { More than one } \\
\text { but not all } \\
\text { (car \& pedestrian) }\end{array}$ & Adults $^{\mathrm{a}}$ & No \\
\hline 35 & $\begin{array}{l}\text { Tronsmoen } \\
{[84]}\end{array}$ & Not specified & $\begin{array}{l}\text { Random sample - } \\
\text { specific criteriab }\end{array}$ & 1419 & 37 & Car & $\begin{array}{l}\text { Other } \\
\text { (18-20 years) }\end{array}$ & No \\
\hline 36 & Twisk et al. [75] & $1-3$ years & $\begin{array}{l}\text { Random sample - } \\
\text { specific criteriab }\end{array}$ & 2310 & n/a & $\begin{array}{l}\text { More than one but } \\
\text { not all (pedestrian \& } \\
\text { cyclist) }\end{array}$ & $\begin{array}{l}\text { Children and } \\
\text { youngsters }\end{array}$ & No \\
\hline 37 & $\begin{array}{l}\text { Warner et al. } \\
{[122]}\end{array}$ & $1-3$ years & $\begin{array}{l}\text { Random sample - } \\
\text { specific criteriab }^{\text {b }}\end{array}$ & 200 & n/a & Car & Adults $^{a}$ & No \\
\hline 38 & $\begin{array}{l}\text { Warner et al. } \\
\text { [122] }\end{array}$ & $1-3$ years & $\begin{array}{l}\text { Random sample - } \\
\text { specific criteriab }^{\text {b }}\end{array}$ & 200 & $\mathrm{n} / \mathrm{a}$ & Car & Adults $^{a}$ & No \\
\hline 39 & $\begin{array}{l}\text { Wood et al. } \\
{[38]}\end{array}$ & $3-5$ years & Random sample & 267 & 75 & Car & Elderly & No \\
\hline 40 & Zhao et al. [39] & $1-3$ years & $\begin{array}{l}\text { Volunteers - Specific } \\
\text { criteriab }^{\mathrm{b}}\end{array}$ & 1533 & $68-72$ & Car & $\begin{array}{l}\text { Other } \\
\text { (16-18 years) }\end{array}$ & No \\
\hline \multicolumn{9}{|c|}{ Online Questionnaire } \\
\hline 41 & $\begin{array}{l}\text { af Wåhlberg } \\
\text { et al. [40] }\end{array}$ & Up to 3 years & $\begin{array}{l}\text { Random sample - } \\
\text { specific criteriab }\end{array}$ & 9824 & $\mathrm{n} / \mathrm{a}$ & $\begin{array}{l}\text { More than one } \\
\text { but not all (car, } \\
\text { bus, police driver, } \\
\text { fleet, truck) }\end{array}$ & Adults $^{a}$ & Yes, other \\
\hline 42 & $\begin{array}{l}\text { af Wåhlberg } \\
\text { [41] }\end{array}$ & $\begin{array}{l}\text { More than } \\
5 \text { years }\end{array}$ & $\begin{array}{l}\text { Random sample - } \\
\text { specific criteriab }^{\text {b }}\end{array}$ & 2665 & $\mathrm{n} / \mathrm{a}$ & Car & $\begin{array}{l}\text { Other } \\
\text { (<25 years })\end{array}$ & No \\
\hline 43 & $\begin{array}{l}\text { Bongers et al. } \\
{[125]}\end{array}$ & $1-3$ years & $\begin{array}{l}\text { Other - specific } \\
\text { criteria }^{\text {b }}\end{array}$ & 1528 & 30 & All types & Adults $^{\mathrm{a}}$ & No \\
\hline 44 & $\begin{array}{l}\text { Boufous et al. } \\
\text { [15] }\end{array}$ & $\begin{array}{l}3 \text { months- } \\
1 \text { year }\end{array}$ & $\begin{array}{l}\text { Random sample - } \\
\text { specific criteriab }\end{array}$ & 2991 & 60 & Car & $\begin{array}{l}\text { Other } \\
\text { (17-24 years) }\end{array}$ & $\begin{array}{l}\text { Yes, to } \\
\text { police } \\
\text { records }\end{array}$ \\
\hline 45 & $\begin{array}{l}\text { Brandau et al. } \\
\text { [42] }\end{array}$ & Not specified & $\begin{array}{l}\text { Volunteers - Specific } \\
\text { criteriab }^{\mathrm{b}}\end{array}$ & 213 & 42 & Motorcycle & $\begin{array}{l}\text { Children and } \\
\text { youngsters }\end{array}$ & No \\
\hline 46 & $\begin{array}{l}\text { Darby et al. } \\
\text { [43] }\end{array}$ & $1-3$ years & Other & 16,004 & 57 & $\begin{array}{l}\text { More than one but } \\
\text { not all (car and van) }\end{array}$ & Adults $^{\mathrm{a}}$ & $\begin{array}{l}\text { Yes, to } \\
\text { company } \\
\text { records }\end{array}$ \\
\hline 47 & $\begin{array}{l}\text { Davey et al. } \\
\text { [80] }\end{array}$ & $1-3$ years & $\begin{array}{l}\text { Volunteers - Specific } \\
\text { criteriab }^{b}\end{array}$ & 4195 & $\mathrm{n} / \mathrm{a}$ & Car & Adults $^{a}$ & No \\
\hline 48 & $\begin{array}{l}\text { De Gruyter } \\
\text { et al. [94] }\end{array}$ & $1-3$ years & $\begin{array}{l}\text { Other - specific } \\
\text { criteriab }^{\text {b }}\end{array}$ & 741 & $\mathrm{n} / \mathrm{a}$ & Motorcycle & & No \\
\hline
\end{tabular}


Table 2 Summary of the studies reviewed based on method (Continued)

\begin{tabular}{|c|c|c|c|c|c|c|c|c|}
\hline Num. & Publication & Recall period & $\begin{array}{l}\text { Selection of } \\
\text { respondents }\end{array}$ & $\begin{array}{l}\text { Number of } \\
\text { respondents }\end{array}$ & $\begin{array}{l}\text { Response rate } \\
(\%)\end{array}$ & $\begin{array}{l}\text { Type of road user / } \\
\text { crashes }\end{array}$ & Age-group & $\begin{array}{l}\text { Link to other } \\
\text { database? }\end{array}$ \\
\hline & & & & & & & $\begin{array}{l}\text { Other } \\
\text { (average age } \\
\text { of } 21.8 \text { years) }\end{array}$ & \\
\hline 49 & $\begin{array}{l}\text { Gliklich et al. } \\
\text { [95] }\end{array}$ & $1-3$ years & $\begin{array}{l}\text { Volunteers - Specific } \\
\text { criteriab }^{\text {b }}\end{array}$ & 1211 & $\mathrm{n} / \mathrm{a}$ & Car & Adults $^{a}$ & No \\
\hline 50 & $\begin{array}{l}\text { Goldenbeld } \\
\text { et al. [22] }\end{array}$ & $1-3$ years & $\begin{array}{l}\text { Volunteers - Specific } \\
\text { criteria }^{\text {b }}\end{array}$ & 2553 & 69 & Bicycle & $\begin{array}{l}\text { Other } \\
\text { (>12 years) }\end{array}$ & No \\
\hline 51 & $\begin{array}{l}\text { Hollingworth } \\
\text { et al. [107] }\end{array}$ & $3-5$ years & $\begin{array}{l}\text { Volunteers - Specific } \\
\text { criteriab }^{b}\end{array}$ & 4961 & $\mathrm{n} / \mathrm{a}$ & Bicycle & $\begin{array}{l}\text { Other } \\
\text { (16-88 years) }\end{array}$ & No \\
\hline 52 & $\begin{array}{l}\text { Lahrmann et al. } \\
\text { [23] }\end{array}$ & 1-3 months & Volunteers & 3845 & 86 & Bicycle & $\begin{array}{l}\text { Other (average } \\
\text { age of } 31 \text { years) }\end{array}$ & No \\
\hline 53 & $\begin{array}{l}\text { Lahrmann et al. } \\
\text { [23] }\end{array}$ & 1-3 months & Volunteers & 6793 & 80 & Bicycle & $\begin{array}{l}\text { Other (average } \\
\text { age of } 46 \text { years) }\end{array}$ & No \\
\hline 54 & $\begin{array}{l}\text { Lahrmann et al. } \\
\text { [24] }\end{array}$ & 1-3 months & $\begin{array}{l}\text { Volunteers - Specific } \\
\text { criteriab }^{\text {b }}\end{array}$ & 6793 & $76-85$ & Bicycle & Adults $^{\mathrm{a}}$ & No \\
\hline 55 & $\begin{array}{l}\text { Loukaitou- } \\
\text { Sideris et al. } \\
\text { [44] }\end{array}$ & $\begin{array}{l}\text { More than } \\
5 \text { years }\end{array}$ & $\begin{array}{l}\text { Volunteers - Specific } \\
\text { criteriab }^{\text {b }}\end{array}$ & 5167 & $1-7$ & $\begin{array}{l}\text { More than one but } \\
\text { not all (pedestrian \& } \\
\text { cyclist) }\end{array}$ & Adults $^{\mathrm{a}}$ & $\begin{array}{l}\text { Yes, to } \\
\text { police } \\
\text { records }\end{array}$ \\
\hline 56 & $\begin{array}{l}\text { Madsen et al. } \\
\text { [45] }\end{array}$ & 1-3 months & $\begin{array}{l}\text { Volunteers - Specific } \\
\text { criteriab }^{b}\end{array}$ & 3845 & 86 & Bicycle & Adults $^{a}$ & No \\
\hline 57 & $\begin{array}{l}\text { Medury et al. } \\
\text { [137] }\end{array}$ & $\begin{array}{l}\text { More than } \\
5 \text { years }\end{array}$ & Volunteers & $\begin{array}{l}\text { Not } \\
\text { mentioned }\end{array}$ & $\mathrm{n} / \mathrm{a}$ & $\begin{array}{l}\text { More than one but } \\
\text { not all (pedestrian \& } \\
\text { cyclist) }\end{array}$ & Adults $^{\mathrm{a}}$ & Yes, other \\
\hline 58 & $\begin{array}{l}\text { O'Connor et al. } \\
\text { [46] }\end{array}$ & Not specified & $\begin{array}{l}\text { Volunteers - Specific } \\
\text { criteriab }^{\text {b }}\end{array}$ & 307 & $\mathrm{n} / \mathrm{a}$ & Car & $\begin{array}{l}\text { Other (average } \\
\text { age of } 19 \text { years) }\end{array}$ & No \\
\hline 59 & Palk et al. [85] & Not specified & $\begin{array}{l}\text { Volunteers - Specific } \\
\text { criteria }^{\text {b }}\end{array}$ & 717 & 14 & Car & $\begin{array}{l}\text { Other } \\
(16-24 \text { years \& } \\
>25 \text { years })\end{array}$ & No \\
\hline 60 & $\begin{array}{l}\text { Poulos et al. } \\
{[129]}\end{array}$ & 1-3 years & $\begin{array}{l}\text { Random sample - } \\
\text { specific criteriab }^{\text {b }}\end{array}$ & 2038 & $\mathrm{n} / \mathrm{a}$ & Bicycle & Adults $^{a}$ & No \\
\hline 61 & $\begin{array}{l}\text { Powell et al. } \\
{[120]}\end{array}$ & 1-3 years & $\begin{array}{l}\text { Random sample - } \\
\text { specific criteriab }^{\text {b }}\end{array}$ & 35,217 & 88 & Car & Adults $^{a}$ & No \\
\hline 62 & $\begin{array}{l}\text { Poulos et al. } \\
\text { [47] }\end{array}$ & $<=1$ month & Volunteers & 2038 & $\mathrm{n} / \mathrm{a}$ & Bicycle & Adults $^{\mathrm{a}}$ & No \\
\hline 63 & $\begin{array}{l}\text { Scott-Parker et } \\
\text { al. [48] }\end{array}$ & $\begin{array}{l}3 \text { months- } \\
1 \text { year }\end{array}$ & $\begin{array}{l}\text { Volunteers - Specific } \\
\text { criteriab }^{\text {b }}\end{array}$ & 378 & 67 & Car & $\begin{array}{l}\text { Other } \\
\text { (17-25 years) }\end{array}$ & No \\
\hline 64 & $\begin{array}{l}\text { Scott-Parker } \\
\text { et al. [114] }\end{array}$ & $\begin{array}{l}3 \text { months- } \\
1 \text { year }\end{array}$ & $\begin{array}{l}\text { Random sample - } \\
\text { specific criteriab }\end{array}$ & 390 & $\mathrm{n} / \mathrm{a}$ & Car & $\begin{array}{l}\text { Other } \\
\text { (17-25 years) }\end{array}$ & No \\
\hline 65 & Shaw et al. [87] & $\begin{array}{l}3 \text { months- } \\
1 \text { year }\end{array}$ & $\begin{array}{l}\text { Random sample - } \\
\text { specific criteriab }^{\text {b }}\end{array}$ & 136 & Other & Bicycle & Adults $^{\mathrm{a}}$ & No \\
\hline 66 & $\begin{array}{l}\text { Stelling- } \\
\text { Konczak et al. } \\
\text { [49] }\end{array}$ & 1-3 years & $\begin{array}{l}\text { Random sample - } \\
\text { specific criteriab }^{\text {b }}\end{array}$ & 2250 & $\mathrm{n} / \mathrm{a}$ & Bicycle & Adults $^{\mathrm{a}}$ & No \\
\hline 67 & Sumer [86] & $3-5$ years & $\begin{array}{l}\text { Volunteers - Specific } \\
\text { criteriab }^{\text {b }}\end{array}$ & 2541 & $\mathrm{n} / \mathrm{a}$ & Car & Adults $^{\mathrm{a}}$ & No \\
\hline 68 & $\begin{array}{l}\text { Thiese et al. } \\
{[128]}\end{array}$ & Lifetime & $\begin{array}{l}\text { Volunteers - Specific } \\
\text { criteria }^{b}\end{array}$ & 797 & 93 & Other (truck drivers) & Adults $^{\mathrm{a}}$ & No \\
\hline 69 & $\begin{array}{l}\text { Thornley et al. } \\
\text { [50] }\end{array}$ & $1-3$ years & $\begin{array}{l}\text { Volunteers - Specific } \\
\text { criteriab }^{\text {b }}\end{array}$ & 2469 & 44 & Bicycle & Adults $^{a}$ & Yes, other \\
\hline 70 & $\begin{array}{l}\text { Tin Tin et al. } \\
{[136]}\end{array}$ & $\begin{array}{l}\text { More than } \\
5 \text { years }\end{array}$ & $\begin{array}{l}\text { Volunteers - Specific } \\
\text { criteriab }^{\text {b }}\end{array}$ & 2438 & 43 & Bicycle & Adults $^{\mathrm{a}}$ & $\begin{array}{l}\text { Yes, to more } \\
\text { than one }\end{array}$ \\
\hline 71 & $\begin{array}{l}\text { Vanparijs et al. } \\
\text { [98] }\end{array}$ & $1-3$ years & $\begin{array}{l}\text { Volunteers - Specific } \\
\text { criteriab }^{\text {b }}\end{array}$ & 163 & 15 & Bicycle & $\begin{array}{l}\text { Children and } \\
\text { youngsters }\end{array}$ & $\begin{array}{l}\text { Yes, to more } \\
\text { than one }\end{array}$ \\
\hline 72 & & $3-5$ years & & 501 & $\mathrm{n} / \mathrm{a}$ & Car & Adults $^{\mathrm{a}}$ & No \\
\hline
\end{tabular}


Table 2 Summary of the studies reviewed based on method (Continued)

\begin{tabular}{|c|c|c|c|c|c|c|c|c|}
\hline Num. & Publication & Recall period & $\begin{array}{l}\text { Selection of } \\
\text { respondents }\end{array}$ & $\begin{array}{l}\text { Number of } \\
\text { respondents }\end{array}$ & $\begin{array}{l}\text { Response rate } \\
(\%)\end{array}$ & $\begin{array}{l}\text { Type of road user / } \\
\text { crashes }\end{array}$ & Age-group & $\begin{array}{l}\text { Link to other } \\
\text { database? }\end{array}$ \\
\hline & $\begin{array}{l}\text { Vingilis et al. } \\
\text { [123] }\end{array}$ & & $\begin{array}{l}\text { Volunteers - Specific } \\
\text { criteriab }^{b}\end{array}$ & & & & & \\
\hline 73 & $\begin{array}{l}\text { Warner et al. } \\
\text { [122] }\end{array}$ & $1-3$ years & $\begin{array}{l}\text { Random sample - } \\
\text { specific criteriab }^{b}\end{array}$ & 200 & $\mathrm{n} / \mathrm{a}$ & Car & Adults $^{a}$ & No \\
\hline \multicolumn{9}{|c|}{ Questionnaire - Not specified further } \\
\hline 74 & $\begin{array}{l}\text { af Wåhlberg } \\
\text { [132] }\end{array}$ & $1-3$ years & $\begin{array}{l}\text { Random sample - } \\
\text { specific criteriab }^{\text {a }}\end{array}$ & 157 & $\mathrm{n} / \mathrm{a}$ & Bus & Adults $^{a}$ & $\begin{array}{l}\text { Yes, to } \\
\text { company } \\
\text { records }\end{array}$ \\
\hline 75 & Chai et al. [93] & $1-3$ years & Volunteers & 38 & $\mathrm{n} / \mathrm{a}$ & Car & Adults $^{\mathrm{a}}$ & No \\
\hline 76 & $\begin{array}{l}\text { Lucidi et al. } \\
\text { [110] }\end{array}$ & $1-3$ years & $\begin{array}{l}\text { Random sample - } \\
\text { specific criteriab }^{\text {b }}\end{array}$ & 485 & $\mathrm{n} / \mathrm{a}$ & Car & Elderly & No \\
\hline 77 & $\begin{array}{l}\text { Mallia et al. } \\
\text { [141] }\end{array}$ & $1-3$ years & $\begin{array}{l}\text { Random sample - } \\
\text { specific criteriab }^{\text {b }}\end{array}$ & 301 & 1 & Bus & Adults $^{a}$ & No \\
\hline 78 & $\begin{array}{l}\text { Nordfjærn et al. } \\
\text { [73] }\end{array}$ & $\begin{array}{l}\text { More than } \\
5 \text { years }\end{array}$ & $\begin{array}{l}\text { Random sample - } \\
\text { specific criteriab }^{\text {b }}\end{array}$ & 299 & 85 & Car & Adults $^{a}$ & No \\
\hline 79 & $\begin{array}{l}\text { Nordfjærn et al. } \\
\text { [73] }\end{array}$ & $\begin{array}{l}\text { More than } \\
5 \text { years }\end{array}$ & $\begin{array}{l}\text { Random sample - } \\
\text { specific criteriab }^{\text {b }}\end{array}$ & 599 & 72 & Car & Adults $^{a}$ & No \\
\hline 80 & $\begin{array}{l}\text { Nordfjærn et al. } \\
\text { [73] }\end{array}$ & $\begin{array}{l}\text { More than } \\
5 \text { years }\end{array}$ & $\begin{array}{l}\text { Random sample - } \\
\text { specific criteriab }^{\text {b }}\end{array}$ & 415 & 70 & Car & Adults $^{a}$ & No \\
\hline 81 & Qu et al. [89] & $1-3$ years & Volunteers & 246 & 80 & Car & Adults $^{\mathrm{a}}$ & No \\
\hline 82 & $\begin{array}{l}\text { Richer and } \\
\text { Bergeron [112] }\end{array}$ & $1-3$ years & $\begin{array}{l}\text { Random sample - } \\
\text { specific criteriab }^{b}\end{array}$ & $\begin{array}{l}72 \text { (driving } \\
\text { simulation), } 75 \\
\text { (self-report } \\
\text { dangerous } \\
\text { driving } \\
\text { behaviour) }\end{array}$ & $\mathrm{n} / \mathrm{a}$ & Car & Adults $^{a}$ & No \\
\hline 83 & $\begin{array}{l}\text { Steg and } \\
\text { Brussel [74] }\end{array}$ & $1-3$ years & $\begin{array}{l}\text { Random sample - } \\
\text { specific criteriab }\end{array}$ & 146 & 37 & Motorcycle & $\begin{array}{l}\text { Other } \\
\text { (16-25 years) }\end{array}$ & No \\
\hline 84 & $\begin{array}{l}\text { Sullman et al. } \\
\text { [97] }\end{array}$ & $1-3$ years & $\begin{array}{l}\text { Other - specific } \\
\text { criteriab }^{\text {b }}\end{array}$ & 339 & $\mathrm{n} / \mathrm{a}$ & Truck & Adults $^{a}$ & No \\
\hline 85 & $\begin{array}{l}\text { Warner et al. } \\
\text { [122] }\end{array}$ & $1-3$ years & $\begin{array}{l}\text { Random sample - } \\
\text { specific criteriab }^{\text {be }}\end{array}$ & 200 & $\mathrm{n} / \mathrm{a}$ & Car & Adults $^{a}$ & No \\
\hline 86 & $\begin{array}{l}\text { Winters and } \\
\text { Branion-Calles } \\
\text { [139] }\end{array}$ & $1-3$ months & $\begin{array}{l}\text { Random sample - } \\
\text { specific criteriab }^{\text {b }}\end{array}$ & 1148 & $\mathrm{n} / \mathrm{a}$ & Bicycle & Adults $^{a}$ & $\begin{array}{l}\text { Yes, to } \\
\text { insurance } \\
\text { records }\end{array}$ \\
\hline 87 & Wundersitz [83] & $1-3$ years & $\begin{array}{l}\text { Random sample - } \\
\text { specific criteriab }^{\text {b }}\end{array}$ & 396 & $\mathrm{n} / \mathrm{a}$ & Car & $\begin{array}{l}\text { Other } \\
\text { (16-24 years) }\end{array}$ & $\begin{array}{l}\text { Yes, to } \\
\text { police } \\
\text { records }\end{array}$ \\
\hline \multicolumn{9}{|c|}{ Face-to-face Interview } \\
\hline 88 & $\begin{array}{l}\text { Begg and } \\
\text { Gulliver [77] }\end{array}$ & $3-5$ years & $\begin{array}{l}\text { Random sample - } \\
\text { specific criteriab }^{\text {b }}\end{array}$ & 933 & 95 & Car & $\begin{array}{l}\text { Other } \\
\text { ( } 21 \text { and } 26 \text { years) }\end{array}$ & Yes, other \\
\hline 89 & $\begin{array}{l}\text { Bon de Sousa } \\
\text { et al. [92] }\end{array}$ & $1-3$ years & $\begin{array}{l}\text { Other - specific } \\
\text { criteria }^{\text {b }}\end{array}$ & 612 & $\mathrm{n} / \mathrm{a}$ & Car & Adults $^{a}$ & No \\
\hline 90 & Chen [70] & Not specified & Random sample & 194 & 41 & Car & Adults $^{a}$ & No \\
\hline 91 & $\begin{array}{l}\text { Cunningham } \\
\text { et al. [51] }\end{array}$ & $1-3$ years & Other & 18,950 & $\mathrm{n} / \mathrm{a}$ & All types & Adults $^{a}$ & $\begin{array}{l}\text { Yes, to } \\
\text { hospital } \\
\text { records }\end{array}$ \\
\hline 92 & $\begin{array}{l}\text { Finestone et al. } \\
\text { [52] }\end{array}$ & $3-5$ years & $\begin{array}{l}\text { Volunteers - Specific } \\
\text { criteriab }^{\text {b }}\end{array}$ & 43 & 77 & Car & Adults $^{\mathrm{a}}$ & $\begin{array}{l}\text { Yes, to } \\
\text { hospital } \\
\text { records }\end{array}$ \\
\hline 93 & $\begin{array}{l}\text { Haymes et al. } \\
\text { [53] }\end{array}$ & $3-5$ years & Other & 95 & 1 & $\begin{array}{l}\text { Unclear (motor } \\
\text { vehicle collision) }\end{array}$ & Elderly & $\begin{array}{l}\text { Yes, to } \\
\text { police } \\
\text { records }\end{array}$ \\
\hline 94 & & & & 1516 & 1 & & Adults $^{\mathrm{a}}$ & No \\
\hline
\end{tabular}


Table 2 Summary of the studies reviewed based on method (Continued)

\begin{tabular}{|c|c|c|c|c|c|c|c|c|}
\hline Num. & Publication & Recall period & $\begin{array}{l}\text { Selection of } \\
\text { respondents }\end{array}$ & $\begin{array}{l}\text { Number of } \\
\text { respondents }\end{array}$ & $\begin{array}{l}\text { Response rate } \\
(\%)\end{array}$ & $\begin{array}{l}\text { Type of road user / } \\
\text { crashes }\end{array}$ & Age-group & $\begin{array}{l}\text { Link to other } \\
\text { database? }\end{array}$ \\
\hline & $\begin{array}{l}\text { Magalhães } \\
\text { et al. [117] }\end{array}$ & $\begin{array}{l}\text { More than } \\
5 \text { years }\end{array}$ & $\begin{array}{l}\text { Random sample - } \\
\text { specific criteriab }\end{array}$ & & & $\begin{array}{l}\text { More than one but } \\
\text { not all (all excluding } \\
\text { trains, streetcars and } \\
\text { the underground) }\end{array}$ & & \\
\hline 95 & $\begin{array}{l}\text { Ngueutsa and } \\
\text { Kouabenan } \\
\text { [54] }\end{array}$ & Not specified & Volunteers & 525 & 95 & All types & $\begin{array}{l}\text { Other } \\
\text { (16-76 years) }\end{array}$ & No \\
\hline 96 & $\begin{array}{l}\text { Zhang et al. } \\
\text { [102] }\end{array}$ & $1-3$ years & $\begin{array}{l}\text { Random sample - } \\
\text { specific criteriab }^{\text {a }}\end{array}$ & 1422 & 95 & $\begin{array}{l}\text { Other } \\
\text { (farm vehicles) }\end{array}$ & Adults $^{a}$ & No \\
\hline \multicolumn{9}{|c|}{ Telephone interview } \\
\hline 97 & $\begin{array}{l}\text { Armstrong } \\
\text { et al. [90] }\end{array}$ & $3-5$ years & $\begin{array}{l}\text { Random sample - } \\
\text { specific criteriab }^{\text {b }}\end{array}$ & 1609 & $\mathrm{n} / \mathrm{a}$ & Car & Adults $^{a}$ & No \\
\hline 98 & Begg et al. [55] & $1-3$ years & $\begin{array}{l}\text { Random sample - } \\
\text { specific criteriab }^{\text {b }}\end{array}$ & 1428 & 36 & Car & $\begin{array}{l}\text { Other } \\
\text { (15-24 years) }\end{array}$ & $\begin{array}{l}\text { Yes, to } \\
\text { police } \\
\text { records }\end{array}$ \\
\hline 99 & $\begin{array}{l}\text { Campbell et al. } \\
\text { [130] }\end{array}$ & $1-3$ years & $\begin{array}{l}\text { Volunteers - Specific } \\
\text { criteriab }^{b}\end{array}$ & 215 & $\mathrm{n} / \mathrm{a}$ & Car & $\begin{array}{l}\text { Children and } \\
\text { youngsters }\end{array}$ & No \\
\hline 100 & Fuller et al. [56] & $1-3$ years & $\begin{array}{l}\text { Random sample - } \\
\text { specific criteriab }^{\text {b }}\end{array}$ & $\begin{array}{l}847 \text { / } 1100 \text { / } \\
1190 \text { (Three } \\
\text { times survey }\end{array}$ & $\mathrm{n} / \mathrm{a}$ & Bicycle & Adults $^{\mathrm{a}}$ & No \\
\hline 101 & $\begin{array}{l}\text { Hoggarth et al. } \\
\text { [135] }\end{array}$ & $1-3$ years & $\begin{array}{l}\text { Volunteers - Specific } \\
\text { criteriab }^{b}\end{array}$ & 58 & $\mathrm{n} / \mathrm{a}$ & Car & Elderly & $\begin{array}{l}\text { Yes, to } \\
\text { police } \\
\text { records }\end{array}$ \\
\hline 102 & Ivers et al. [57] & $\begin{array}{l}3 \text { months- } \\
1 \text { year }\end{array}$ & $\begin{array}{l}\text { Random sample - } \\
\text { specific criteriab }^{\text {b }}\end{array}$ & $\begin{array}{l}2399 \\
\text { (baseline), } 2128 \\
\text { (3 months), } \\
2102 \\
\text { (12 months) }\end{array}$ & $88-89$ & Motorcycle & Adults $^{a}$ & $\begin{array}{l}\text { Yes, to } \\
\text { police } \\
\text { records }\end{array}$ \\
\hline 103 & Johnson [103] & $1-3$ years & $\begin{array}{l}\text { Random sample - } \\
\text { specific criteriab }^{\text {b }}\end{array}$ & 504 & $\mathrm{n} / \mathrm{a}$ & Motorcycle & Adults $^{\mathrm{a}}$ & $\begin{array}{l}\text { Yes, to } \\
\text { police } \\
\text { records }\end{array}$ \\
\hline 104 & Ross et al. [121] & $1-3$ years & $\begin{array}{l}\text { Random sample - } \\
\text { specific criteriab }^{\text {b }}\end{array}$ & 350 & 50 & Car & Elderly & $\begin{array}{l}\text { Yes, to } \\
\text { police } \\
\text { records }\end{array}$ \\
\hline 105 & $\begin{array}{l}\text { Mann et al. } \\
\text { [142] }\end{array}$ & $1-3$ years & Random sample & 4897 & $54-63$ & Car & Adults $^{a}$ & No \\
\hline 106 & $\begin{array}{l}\text { Mann et al. } \\
{[81]}\end{array}$ & $1-3$ years & Random sample & 2676 & $54-62$ & Car & Adults $^{a}$ & No \\
\hline 107 & $\begin{array}{l}\text { Mann et al. } \\
{[118]}\end{array}$ & $1-3$ years & Random sample & 5298 & $56-61$ & Car & Adults $^{\mathrm{a}}$ & No \\
\hline 108 & $\begin{array}{l}\text { Mann et al. } \\
\text { [119] }\end{array}$ & $1-3$ years & Random sample & 8481 & $53-61$ & Car & Adults $^{a}$ & No \\
\hline 109 & $\begin{array}{l}\text { McEvoy et al. } \\
{[78]}\end{array}$ & $1-3$ years & $\begin{array}{l}\text { Random sample - } \\
\text { specific criteriab }^{\text {b }}\end{array}$ & 1347 & 48 & Car & Adults $^{a}$ & No \\
\hline 110 & $\begin{array}{l}\text { Stoduto et al. } \\
{[58]}\end{array}$ & $1-3$ years & $\begin{array}{l}\text { Random sample - } \\
\text { specific criteriab }\end{array}$ & 7284 & $\mathrm{n} / \mathrm{a}$ & Car & Adults $^{\mathrm{a}}$ & No \\
\hline 111 & $\begin{array}{l}\text { Valencia-Martin } \\
\text { et al. [143] }\end{array}$ & $1-3$ years & Random sample & 12,037 & 65 & $\begin{array}{l}\text { More than one but } \\
\text { not all (Automobile } \\
\text { and motorcycle) }\end{array}$ & Adults $^{a}$ & No \\
\hline 112 & $\begin{array}{l}\text { Vingilis et al. } \\
\text { [126] }\end{array}$ & $1-3$ years & $\begin{array}{l}\text { Random sample - } \\
\text { specific criteriab }\end{array}$ & 4014 & 53 & Car & Adults $^{\mathrm{a}}$ & $\begin{array}{l}\text { Yes, to } \\
\text { police } \\
\text { records }\end{array}$ \\
\hline 113 & $\begin{array}{l}\text { Wickens et al. } \\
{[100]}\end{array}$ & $1-3$ years & $\begin{array}{l}\text { Random sample - } \\
\text { specific criteriab }^{\text {a }}\end{array}$ & 12,830 & $\mathrm{n} / \mathrm{a}$ & All types & Adults $^{\mathrm{a}}$ & No \\
\hline 114 & $\begin{array}{l}\text { Wickens et al. } \\
\text { [99] }\end{array}$ & $1-3$ years & $\begin{array}{l}\text { Random sample - } \\
\text { specific criteriab }\end{array}$ & 3428 & 51 & All types & Adults $^{\mathrm{a}}$ & No \\
\hline
\end{tabular}


Table 2 Summary of the studies reviewed based on method (Continued)

\begin{tabular}{|c|c|c|c|c|c|c|c|c|}
\hline Num. & Publication & Recall period & $\begin{array}{l}\text { Selection of } \\
\text { respondents }\end{array}$ & $\begin{array}{l}\text { Number of } \\
\text { respondents }\end{array}$ & $\begin{array}{l}\text { Response rate } \\
(\%)\end{array}$ & $\begin{array}{l}\text { Type of road user / } \\
\text { crashes }\end{array}$ & Age-group & $\begin{array}{l}\text { Link to other } \\
\text { database? }\end{array}$ \\
\hline 115 & $\begin{array}{l}\text { Wickens et al. } \\
\text { [101] }\end{array}$ & $1-3$ years & $\begin{array}{l}\text { Random sample - } \\
\text { specific criteriab }^{\text {b }}\end{array}$ & 11,263 & $45-57$ & $\begin{array}{l}\text { More than one } \\
\text { but not all } \\
\text { (car, SUV, truck) }\end{array}$ & Adults $^{a}$ & No \\
\hline \multicolumn{9}{|c|}{ Interview - Not specified further } \\
\hline 116 & $\begin{array}{l}\text { Asbridge et al. } \\
\text { [69] }\end{array}$ & $1-3$ years & $\begin{array}{l}\text { Random sample - } \\
\text { specific criteriab }\end{array}$ & 393 & 73 & Bicycle & $\begin{array}{l}\text { Other } \\
\text { (>16 years) }\end{array}$ & No \\
\hline 117 & Isho et al. [108] & $1-3$ years & $\begin{array}{l}\text { Volunteers - Specific } \\
\text { criteriab }^{\text {b }}\end{array}$ & 24 & $\mathrm{n} / \mathrm{a}$ & $\begin{array}{l}\text { Other (fall risk } \\
\text { of elderly) }\end{array}$ & Elderly & No \\
\hline 118 & $\begin{array}{l}\text { Singletary et al. } \\
\text { [138] }\end{array}$ & $1-3$ years & $\begin{array}{l}\text { Volunteers - Specific } \\
\text { criteriab }^{\text {b }}\end{array}$ & 1747 & 87 & Car & Elderly & $\begin{array}{l}\text { Yes, to } \\
\text { police } \\
\text { records }\end{array}$ \\
\hline \multicolumn{9}{|c|}{ More than one method } \\
\hline 119 & $\begin{array}{l}\text { Anstey et al. } \\
{[134]}\end{array}$ & $3-5$ years & $\begin{array}{l}\text { Volunteers - Specific } \\
\text { criteriab }^{\text {b }}\end{array}$ & 509 & 100 & Car & Elderly & $\begin{array}{l}\text { Yes, to } \\
\text { police } \\
\text { records }\end{array}$ \\
\hline 120 & $\begin{array}{l}\text { Antonopoulos } \\
\text { et al. [104] }\end{array}$ & $1-3$ months & Random sample & 978 & $\mathrm{n} / \mathrm{a}$ & $\begin{array}{l}\text { More than one } \\
\text { but not all } \\
\text { (motorcycle \& car) }\end{array}$ & Adults $^{\mathrm{a}}$ & No \\
\hline 121 & $\begin{array}{l}\text { Boufous et al. } \\
\text { [59] }\end{array}$ & Not specified & Other & 20,822 & 16 & Car & $\begin{array}{l}\text { Other } \\
\text { (17-24 years) }\end{array}$ & $\begin{array}{l}\text { Yes, to } \\
\text { police } \\
\text { records }\end{array}$ \\
\hline 122 & $\begin{array}{l}\text { de Rome et al. } \\
\text { [105] }\end{array}$ & $\begin{array}{l}<=1 \text { month \& } \\
\text { previous } \\
\text { crash history } \\
\text { is not further } \\
\text { specified }\end{array}$ & $\begin{array}{l}\text { Volunteers - Specific } \\
\text { criteriab }^{b}\end{array}$ & 202 & 65 & Bicycle & Adults $^{a}$ & $\begin{array}{l}\text { Yes, to } \\
\text { hospital } \\
\text { records }\end{array}$ \\
\hline 123 & $\begin{array}{l}\text { Hassan and } \\
\text { Abdel-Aty [91] }\end{array}$ & Not specified & $\begin{array}{l}\text { Random sample - } \\
\text { specific criteriab }^{\text {b }}\end{array}$ & 680 & $\begin{array}{l}26 \text { (paper } \\
\text { questionnaire) }\end{array}$ & Car & $\begin{array}{l}\text { Other } \\
\text { (16-24 years) }\end{array}$ & No \\
\hline 124 & $\begin{array}{l}\text { Haworth and } \\
\text { Schramm [60] }\end{array}$ & $1-3$ years & $\begin{array}{l}\text { Volunteers - Specific } \\
\text { criteriab }^{b}\end{array}$ & 2532 & $\mathrm{n} / \mathrm{a}$ & $\begin{array}{l}\text { More than one but } \\
\text { not all (pedestrian \& } \\
\text { cyclist) }\end{array}$ & Adults $^{a}$ & No \\
\hline 125 & $\begin{array}{l}\text { Huang et al. } \\
\text { [61] }\end{array}$ & $1-3$ years & $\begin{array}{l}\text { Random sample - } \\
\text { specific criteriab }^{\text {b }}\end{array}$ & 500 & $79-83$ & Car & Adults $^{a}$ & No \\
\hline 126 & $\begin{array}{l}\text { de Rome et al. } \\
\text { [140] }\end{array}$ & Not specified & $\begin{array}{l}\text { Volunteers - Specific } \\
\text { criteriab }^{\text {b }}\end{array}$ & 313 & 84 & Bicycle & Adults $^{a}$ & $\begin{array}{l}\text { Yes, to } \\
\text { hospital } \\
\text { records }\end{array}$ \\
\hline 127 & $\begin{array}{l}\text { Poulos et al. } \\
\text { [111] }\end{array}$ & $1-3$ months & $\begin{array}{l}\text { Volunteers - Specific } \\
\text { criteriab }^{\text {b }}\end{array}$ & 2038 & $\mathrm{n} / \mathrm{a}$ & Bicycle & Adults $^{\mathrm{a}}$ & No \\
\hline 128 & $\begin{array}{l}\text { Saengsuwan } \\
\text { et al. [62] }\end{array}$ & Not specified & $\begin{array}{l}\text { Random sample - } \\
\text { specific criteriab }\end{array}$ & 203 & $\mathrm{n} / \mathrm{a}$ & $\begin{array}{l}\text { More than one but } \\
\text { not all (motorcycle, } \\
2 \text { or } 3 \text {-wheeled } \\
\text { motorbike } \\
\text { merchant vehicle, car) }\end{array}$ & Adults $^{\mathrm{a}}$ & No \\
\hline 129 & $\begin{array}{l}\text { Sakashita et al. } \\
\text { [63] }\end{array}$ & $1-3$ years & $\begin{array}{l}\text { Random sample - } \\
\text { specific criteriab }\end{array}$ & 1305 & 55 & Motorcycle & Adults $^{a}$ & $\begin{array}{l}\text { Yes, to } \\
\text { police } \\
\text { records }\end{array}$ \\
\hline 130 & $\begin{array}{l}\text { Scialfa et al. } \\
{[64]}\end{array}$ & $1-3$ years & $\begin{array}{l}\text { Volunteers - Specific } \\
\text { criteriab }^{\text {b }}\end{array}$ & 56 & $\mathrm{n} / \mathrm{a}$ & Car & $\begin{array}{l}\text { Other } \\
\text { (18-25 years) }\end{array}$ & No \\
\hline 131 & $\begin{array}{l}\text { Sullman et al. } \\
\text { [65] }\end{array}$ & Life time & $\begin{array}{l}\text { Random sample - } \\
\text { specific criteriab }^{\text {b }}\end{array}$ & 294 & 87 & All types & $\begin{array}{l}\text { Children and } \\
\text { youngsters }\end{array}$ & No \\
\hline 132 & $\begin{array}{l}\text { Washington } \\
\text { et al. [66] }\end{array}$ & $1-3$ years & $\begin{array}{l}\text { Random sample - } \\
\text { specific criteriab }^{\text {a }}\end{array}$ & 2500 & $\mathrm{n} / \mathrm{a}$ & Bicycle & Adults $^{\mathrm{a}}$ & No \\
\hline \multicolumn{9}{|c|}{ Not clearly stated } \\
\hline 133 & $\begin{array}{l}\text { Langford et al. } \\
\text { [67] }\end{array}$ & $1-3$ years & $\begin{array}{l}\text { Random sample - } \\
\text { specific criteriab }^{\text {b }}\end{array}$ & 1222 & 99 & Car & Elderly & Yes, other \\
\hline
\end{tabular}


Table 2 Summary of the studies reviewed based on method (Continued)

\begin{tabular}{|c|c|c|c|c|c|c|c|c|}
\hline Num. & Publication & Recall period & $\begin{array}{l}\text { Selection of } \\
\text { respondents }\end{array}$ & $\begin{array}{l}\text { Number of } \\
\text { respondents }\end{array}$ & $\begin{array}{l}\text { Response rate } \\
(\%)\end{array}$ & $\begin{array}{l}\text { Type of road user / } \\
\text { crashes }\end{array}$ & Age-group & $\begin{array}{l}\text { Link to other } \\
\text { database? }\end{array}$ \\
\hline 134 & $\begin{array}{l}\text { Verschuur and } \\
\text { Hurts [68] }\end{array}$ & $1-3$ years & Random sample & 743 & $\mathrm{n} / \mathrm{a}$ & Car & Adults $^{\mathrm{a}}$ & $\begin{array}{l}\text { Yes, to } \\
\text { company } \\
\text { records }\end{array}$ \\
\hline
\end{tabular}

n/a Not available

${ }^{a}$ Adults is legal age of obtaining driving license and no upper limit

${ }^{b}$ Specific criteria can be people with the certain illness or group of road users (e.g. children, youngsters, novice drivers, elderly)

\section{Acknowledgements}

This review paper is a part of the InDeV project funded by H2020-EU (No. 635895). Thanks also to everyone who was directly or indirectly involved in the success of this research.

\section{Authors' contributions}

All authors read and approved the final manuscript.

\section{Competing interests}

The authors declare that they have no competing interests.

\section{Publisher's Note}

Springer Nature remains neutral with regard to jurisdictional claims in published maps and institutional affiliations.

\section{Author details}

'Department of Technology and Society, Lund University, P.O. Box 118, John Ericssons väg 1, SE-22100 Lund, Sweden. ${ }^{2}$ Faculty of Civil Engineering, Universiti Teknologi MARA, 40450 Shah Alam, Malaysia. ${ }^{3}$ Aalborg Municipality, Stigsborg Brygge 5, DK-9400 Nørresundby, Denmark. ${ }^{4}$ Department of Civil Engineering, Aalborg University, Thomas Manns vej 23, DK-9220 Aalborg Ø, Denmark.

\section{Received: 8 March 2018 Accepted: 4 June 2018}

Published online: 13 June 2018

\section{References}

1. Elvik R, Høye A, Vaa T, Sørensen M (2009). The handbook of road safety measures (2nd ed.). Bingley: Emerald Group Publishing Limited

2. Agerholm N, Andersen CS (2015) Accident risk and factors regarding nonmotorised road users: a central road safety challenge with deficient data. Latin Am J Manag Sustain Dev 2(2):102-111

3. Alsop J, Langley J (2001) Under-reporting of motor vehicle traffic crash victims in New Zealand. Accid Anal Prev 33(3):353-359. https://doi.org/10. 1016/S0001-4575(00)00049-X

4. Aptel I, Salmi LR, Masson F, Bourdé A, Henrion G, Erny P (1999) Road accident statistics: discrepancies between police and hospital data in a French island. Accid Anal Prev 31(1):101-108. https://doi.org/10.1016/500014575(98)00051-7

5. Elvik R, Mysen AB (1999) Incomplete accident reporting: meta-analysis of studies made in 13 countries. J Transp Res Board Transp Res Rec 1665:133-140

6. Rosman DL, Knuiman MW (1994) A comparison of hospital and police road injury data. Accid Anal Prev 26(2):215-222. https://doi.org/10.1016/00014575(94)90091-4

7. WHO (2015) Global status report on road safety 2015. World Health Organization, Italy. http://www.who.int/violence_injury_prevention/road_ safety_status/2015/en/

8. Amoros E, Martin J-L, Laumon B (2006) Under-reporting of road crash casualties in France. Accid Anal Prev 38(4):627-635. https://doi.org/10.1016/j. aap.2005.11.006

9. Janstrup KH, Kaplan S, Hels T, Lauritsen J, Prato CG (2016) Understanding traffic crash under-reporting: linking police and medical records to individual and crash characteristics. Traffic Inj Prev 17(6):580-584. https://doi. org/10.1080/15389588.2015.1128533

10. Rosman DL (2001) The western Australian road injury database (1987-1996): ten years of linked police, hospital and death records of road crashes and injuries. Accid Anal Prev 33(1):81-88. https://doi.org/10.1016/S00014575(00)00018-X

11. Kamaluddin NA, Abd Rahman MF, Várhelyi A (2018) Matching of police and hospital road crash casualty records - a data-linkage study in Malaysia. International Journal of Injury Control and Safety Promotion. https://doi.org/ 10.1080/17457300.2018.1476385.

12. Salifu M, Ackaah W (2012) Under-reporting of road traffic crash data in Ghana. Int J Inj Control Saf Promot 19(4):331-339. https://doi.org/10.1080/ 17457300.2011.628752

13. Marottoli RA, Cooney LM Jr, Tinetti ME (1997) Self-report versus state records for identifying crashes among older drivers. J Gerontol A Biol Sci Med Sci 52((3):M184-M187

14. McGwin G, Owsley C, Ball K (1998) Identifying crash involvement among older drivers: agreement between self-report and state records. Accid Anal Prev 30(6):781-791. https://doi.org/10.1016/S0001-4575(98)00031-1

15. Boufous S, Ivers R, Senserrick T, Stevenson M, Norton R, Williamson A (2010) Accuracy of self-report of on-road crashes and traffic offences in a cohort of young drivers: the DRIVE study. Inj Prev 16(4):275-277. https://doi.org/10. 1136/ip.2009.024877

16. Mock C, Acheampong F, Adjei S, Koepsell T (1999) The effect of recall on estimation of incidence rates for injury in Ghana. Int J Epidemiol 28(4):750-755

17. Lajunen T, Özkan T (2011) Chapter 4 - Self-Report Instruments and Methods A2 - Porter, Bryan E. In: Handbook of traffic psychology. Academic Press, San Diego, pp 43-59. https://doi.org/10.1016/B978-0-12-381984-0.10004-9

18. Violanti JM, Marshall JR (1996) Cellular phones and traffic accidents: an epidemiological approach. Accid Anal Prev 28(2):265-270. https://doi.org/10. 1016/0001-4575(95)00070-4

19. af Wåhlberg AE (2002) On the validity of self-reported traffic accident data. Paper presented at the E140 proceedings of the 2nd safety on road international conference

20. Bajaj JS, Saeian K, Schubert CM, Hafeezullah M, Franco J, Varma RR, Gibson DP, Hoffmann RG, Stravitz RT, Heuman DM, Sterling RK, Shiffman M, Topaz A, Boyett S, Bell D, Sanyal AJ (2009) Minimal hepatic encephalopathy is associated with motor vehicle crashes: the reality beyond the driving test. Hepatology 50(4):1175-1183. https://doi.org/10.1002/hep.23128

21. Berecki-Gisolf J, Yiengprugsawan V, Kelly M, McClure R, Seubsman SA, Sleigh A (2015) The impact of the thai motorcycle transition on road traffic injury: Thai cohort study results. PLoS One 10(3). https://doi.org/10.1371/journal.pone.0120617

22. Goldenbeld C, Houtenbos M, Ehlers E, De Waard D (2012) The use and risk of portable electronic devices while cycling among different age groups. J Saf Res 43(1):1-8. https://doi.org/10.1016/j.jsr.2011.08.007

23. Lahrmann H, Madsen TKO, Olesen AV (2017) Randomized trials and self-reported accidents as a method to study safety-enhancing measures for cyclists - two case studies. Accid Anal Prev. https://doi.org/10.1016/j.aap.2017.07.019

24. Lahrmann H, Madsen TKO, Olesen AV, Madsen JCO, Hels T (2017) The effect of a yellow bicycle jacket on cyclist accidents. Saf Sci. https://doi.org/10. 1016/j.ssci.2017.08.001

25. Chang H-L, Yeh T-H (2007) Motorcyclist accident involvement by age, gender, and risky behaviors in Taipei, Taiwan. Transport Res F: Traffic Psychol Behav 10(2):109-122. https://doi.org/10.1016/j.trf.2006.08.001

26. Horswill MS, Anstey KJ, Hatherly CG, Wood JM (2010) The crash involvement of older drivers is associated with their hazard perception latencies. J Int Neuropsychol Soc 16(5):939-944. https://doi.org/10.1017/ S135561771000055X

27. Ibrahim JM, Day H, Hirshon JM, El-Setouhy M (2012) Road risk-perception and pedestrian injuries among students at Ain Shams University, Cairo, Egypt. J Inj Violence Res 4(2):65-72. 
28. Jiménez-Mejías E, Lardelli-Claret P, Jiménez-Moleón JJ, Amezcua-Prieto C, Manzanero JP, Luna-del-Castillo JD (2013) Decomposing the association between the amount of exposure and the frequency of self-reported involvement in a road crash. Inj Prev 19(4):280-283. https://doi.org/10.1136/ injuryprev-2012-040467

29. Koekemoer K, Van Gesselleen M, Van Niekerk A, Govender R, Van AAB (2017) Child pedestrian safety knowledge, behaviour and road injury in Cape Town, South Africa. Accid Anal Prev 99:202-209. https://doi.org/10.1016/j. aap.2016.11.020

30. Laapotti S, Keskinen E, Hatakka M, Hernetkoski K, Katila A, Peräaho M, Salo I (2006) Driving circumstances and accidents among novice drivers. Traffic Inj Prev 7(3):232-237. https://doi.org/10.1080/15389580600668537

31. Lafont S, Laumon B, Helmer C, Dartigues JF, Fabrigoule C (2008) Driving cessation and self-reported car crashes in older drivers: the impact of cognitive impairment and dementia in a population-based study. J Geriatr Psychiatry Neurol 21(3):171-182. https://doi.org/10.1177/0891988708316861

32. Ma M, Yan X, Huang H, Abdel-Aty M (2010) Safety of public transportation occupational drivers: risk perception, attitudes, and driving behavior. Transp Res Rec. https://doi.org/10.3141/2145-09

33. Schanke AK, Rike PO, Mølmen A, Østen PE (2008) Driving behaviour after brain injury: a follow-up of accident rate and driving patterns 6-9 years post-injury. J Rehabil Med 40(9):733-736. https://doi.org/10.2340/165019770256

34. Scott-Parker B, Watson B, King MJ, Hyde MK (2014) "i drove after drinking alcohol" and other risky driving behaviours reported by young novice drivers. Accid Anal Prev 70:65-73. https://doi.org/10.1016/j.aap. 2014.03.002

35. Sirin H, Weiss HB, Sauber-Schatz EK, Dunning K (2007) Seat belt use, counseling and motor-vehicle injury during pregnancy: results from a multistate population-based survey. Matern Child Health J 11(5):505-510. https:// doi.org/10.1007/s10995-007-0190-7

36. Stephan K, Kelly M, McClure R, Seubsman S-a, Yiengprugsawan V, Bain C, Sleigh A (2011) Distribution of transport injury and related risk behaviours in a large national cohort of Thai adults. Accid Anal Prev 43(3):1062-1067. https://doi.org/10.1016/j.aap.2010.12.011

37. Tetali S, Edwards P, Murthy GVS, Roberts I (2016) Road traffic injuries to children during the school commute in Hyderabad, India: cross-sectional survey. Inj Prev 22(3):171-175.

38. Wood JM, Anstey K, Lacherez PF, Kerr GK, Mallon K, Lord SR (2009) The onroad difficulties of older drivers and their relationship with self-report motor vehicle crashes. J Am Geriatr Soc 57(11):2062-2069.

39. Zhao J, Mann RE, Chipman M, Adlaf E, Stoduto G, Smart RG (2006) The impact of driver education on self-reported collisions among young drivers with a graduated license. Accid Anal Prev 38(1):35-42. https://doi.org/10. 1016/j.aap.2005.06.019

40. af Wåhlberg AE, Dorn L, Kline T (2010) The effect of social desirability on self reported and recorded road traffic accidents. Transport Res F: Traffic Psychol Behav 13(2):106-114. https://doi.org/10.1016/j.trf.2009.11.004

41. af Wåhlberg AE (2011) Re-education of young driving offenders: effects on recorded offences and self-reported collisions. Transport Res F: Traffic Psychol Behav 14(4):291-299.

42. Brandau H, Daghofer F, Hofmann M, Spitzer P (2011) Personality subtypes of young moped drivers, their relationship to risk-taking behavior and involvement in road crashes in an Austrian sample. Accid Anal Prev 43(5): 1713-1719. https://doi.org/10.1016/j.aap.2011.03.030

43. Darby P, Murray W, Raeside R (2009) Applying online fleet driver assessment to help identify, target and reduce occupational road safety risks. Saf Sci 47(3):436-442. https://doi.org/10.1016/j.ssci.2008.05.004

44. Loukaitou-Sideris A, Medury A, Fink C, Grembek O, Shafizadeh K, Wong N, Orrick P (2014) Crashes on and near college campuses: a comparative analysis of pedestrian and bicyclist safety. J Am Plan Assoc 80(3):198-217. https://doi.org/10.1080/01944363.2014.978354

45. Madsen JCO, Andersen T, Lahrmann HS (2013) Safety effects of permanent running lights for bicycles: a controlled experiment. Accid Anal Prev 50:820 829. https://doi.org/10.1016/j.aap.2012.07.006

46. O'Connor SS, Shain LM, Whitehill JM, Ebel BE (2017) Measuring a conceptual model of the relationship between compulsive cell phone use, in-vehicle cell phone use, and motor vehicle crash. Accid Anal Prev 99(Part A):372-378

47. Poulos RG, Hatfield J, Rissel C, Flack LK, Shaw L, Grzebieta R, McIntosh AS (2017) Near miss experiences of transport and recreational cyclists in New
South Wales, Australia. Findings from a prospective cohort study. Accid Anal Prev 101:143-153. https://doi.org/10.1016/j.aap.2017.01.020

48. Scott-Parker B, Watson B, King MJ, Hyde MK (2013) Revisiting the concept of the 'problem young driver' within the context of the 'young driver problem': who are they? Accid Anal Prev 59:144-152. https://doi.org/10. 1016/j.aap.2013.05.009

49. Stelling-Konczak A, Hagenzieker M, Van Wee GP (2014) Cyclists and traffic sounds: the results of an internet survey. In: International cycling safety conference 2014, Göteborg, p 22.

50. Thornley SJ, Woodward A, Langley JD, Ameratunga SN, Rodgers A (2008) Conspicuity and bicycle crashes: preliminary findings of the Taupo Bicycle study. Inj Prev 14(1):11-18. https://doi.org/10.1136/ip.2007.016675

51. Cunningham R, Carter K, Connor J, Fawcett J (2010) Does health status matter for the risk of injury? N Z Med J 123(1327):35-46.

52. Finestone HM, Guo M, O'Hara P, Greene-Finestone L, Marshall SC, Hunt L, Jessup A, Biggs J (2011) Department of transportation vs self-reported data on motor vehicle collisions and driving convictions for stroke survivors: do they agree? Traffic Inj Prev 12(4):327-332. https://doi.org/10.1080/15389588. 2011.581716

53. Haymes SA, LeBlanc RP, Nicolela MT, Chiasson LA, Chauhan BC (2007) Risk of falls and motor vehicle collisions in glaucoma. Investig Ophthalmol Vis Sci 48(3):1149-1155. https://doi.org/10.1167/iovs.06-0886

54. Ngueutsa R, Kouabenan DR (2017) Accident history, risk perception and traffic safe behaviour. Ergonomics 60(9):1273-1282.

55. Begg DJ, Langley JD, Brookland RL, Ameratunga S, Gulliver P (2014) Prelicensed driving experience and car crash involvement during the learner and restricted, licence stages of graduated driver licensing: findings from the New Zealand drivers study. Accid Anal Prev 62:153-160. https://doi.org/ 10.1016/j.aap.2013.08.027

56. Fuller D, Gauvin L, Morency P, Kestens Y, Drouin L (2013) The impact of implementing a public bicycle share program on the likelihood of collisions and near misses in Montreal, Canada. Prev Med 57(6):920-924. https://doi. org/10.1016/j.ypmed.2013.05.028

57. Ivers RQ, Sakashita C, Senserrick T, Elkington J, Lo S, Boufous S, de Rome L (2016) Does an on-road motorcycle coaching program reduce crashes in novice riders? A randomised control trial. Accid Anal Prev 86:40-46. https:// doi.org/10.1016/j.aap.2015.10.015

58. Stoduto G, Mann RE, lalomiteanu A, Wickens CM, Brands B (2012) Examining the link between collision involvement and cocaine use. Drug Alcohol Depend 123(1-3):260-263. https://doi.org/10.1016/j. drugalcdep.2011.10.008

59. Boufous S, Ivers R, Senserrick T, Norton R, Stevenson M, Chen HY, Lam LT (2010) Risky driving behavior and road traffic crashes among young Asian Australian drivers: findings from the DRIVE study. Traffic Inj Prev 11(3):222-227. https://doi.org/10.1080/15389581003614888

60. Haworth N, Schramm A (2011) Adults cycling on the footpath: what do the data show? In: Autralasian road safety research, policing and education conference, Perth convention and exhibition centre, Perth, WA, p 10

61. Huang Y-H, Zhang W, Murphy L, Shi G, Lin Y (2011) Attitudes and behavior of Chinese drivers regarding seatbelt use. Accid Anal Prev 43(3):889-897. https://doi.org/10.1016/j.aap.2010.11.009

62. Saengsuwan J, Laohasiriwong W, Boonyaleepan S, Sawanyawisuth K, Tiamkao S, Talkul A (2014) Seizure-related vehicular crashes and falls with injuries for people with epilepsy (PWE) in northeastern Thailand. Epilepsy Behav 32:49-54. https://doi.org/10.1016/j.yebeh.2013.12.021

63. Sakashita C, Senserrick T, Lo S, Boufous S, de Rome L, Ivers R (2014) The motorcycle rider behavior questionnaire: psychometric properties and application amongst novice riders in Australia. Transport Res F: Traffic Psychol Behav 22:126-139.

64. Scialfa CT, Borkenhagen D, Lyon J, Deschênes M (2013) A comparison of static and dynamic hazard perception tests. Accid Anal Prev 51:268-273. https://doi.org/10.1016/j.aap.2012.12.006

65. Sullman MJM, Thomas A, Stephens AN (2012) The road user behaviour of school students in Belgium. Accid Anal Prev 48:495-504. https://doi.org/10. 1016/j.aap.2012.03.004

66. Washington S, Haworth N, Schramm A (2012) Relationships between selfreported bicycling injuries and perceived risk of cyclists in Queensland, Australia. Transp Res Rec (2314):57-65.

67. Langford J, Charlton JL, Koppel S, Myers A, Tuokko H, Marshall S, Man-SonHing M, Darzins P, Di Stefano M, Macdonald W (2013) Findings from the Candrive/Ozcandrive study: low mileage older drivers, crash risk and 
reduced fitness to drive. Accid Anal Prev 61:304-310. https://doi.org/10. 1016/j.aap.2013.02.006

68. Verschuur WLG, Hurts K (2008) Modeling safe and unsafe driving behaviour. Accid Anal Prev 40(2):644-656. https://doi.org/10.1016/j.aap.2007.09.001

69. Asbridge M, Mann R, Cusimano MD, Tallon JM, Pauley C, Rehm J (2014) Cyclingrelated crash risk and the role of cannabis and alcohol: a case-crossover study. Prev Med 66:80-86. https:/doi.org/10.1016/j.ypmed.2014.06.006

70. Chen Y-L (2007) Driver personality characteristics related to self-reported accident involvement and mobile phone use while driving. Saf Sci 45(8): 823-831. https://doi.org/10.1016/j.ssci.2006.06.004

71. King Y, Parker D (2008) Driving violations, aggression and perceived consensus. Eur Rev Appl Psychol 58(1):43-49. https:/doi.org/10.1016/j.erap.2006.05.001

72. Korpinen L, Pääkkönen R (2012) Accidents and close call situations connected to the use of mobile phones. Accid Anal Prev 45:75-82. https:// doi.org/10.1016/j.aap.2011.11.016

73. Nordfjærn T, Jørgensen S, Rundmo T (2012) Cultural and sociodemographic predictors of car accident involvement in Norway, Ghana, Tanzania and Uganda. Saf Sci 50(9):1862-1872. https://doi.org/10.1016/j.ssci. 2012.05.003

74. Steg L, Brussel A (2009) Accidents, aberrant behaviours, and speeding of young moped riders. Transport Res F: Traffic Psychol Behav 12(6):503-511. https://doi.org/10.1016/j.trf.2009.09.001

75. Twisk DAM, Commandeur JJF, Vlakveld WP, Shope JT, Kok G (2015) Relationships amongst psychological determinants, risk behaviour, and road crashes of young adolescent pedestrians and cyclists: implications for road safety education programmes. Transport Res F: Traffic Psychol Behav 30:4556. https://doi.org/10.1016/j.trf.2015.01.011

76. Bagdadi O, Várhelyi A (2011) Jerky driving - an indicator of accident proneness? Accid Anal Prev 43(4):1359-1363. https://doi.org/10.1016/j.aap. 2011.02.009

77. Begg DJ, Gulliver P (2008) A longitudinal examination of the relationship between adolescent problem behaviors and traffic crash involvement during young adulthood. Traffic Inj Prev 9(6):508-514. https://doi.org/10. 1080/15389580802335117

78. McEvoy SP, Stevenson MR, Woodward M (2006) The impact of driver distraction on road safety: results from a representative survey in two Australian states. Inj Prev 12(4):242-247. https://doi.org/10.1136/ip.2006.012336

79. Pizza F, Contardi S, Antognini AB, Zagoraiou M, Borrotti M, Mostacci B, Mondini S, Cirignotta F (2010) Sleep quality and motor vehicle crashes in adolescents. J Clin Sleep Med 6(1):41-45.

80. Davey J, Freeman J, Wishart D (2006) A study predicting self-reported crashes among fleet drivers. In: Australasian road safety research policing education conference, 2006, Surfers Paradise, Queensland, Australia, p 11

81. Mann RE, Adlaf EM, Zhao J, Stoduto G, lalomiteanu A, Smart RG, Asbridge M (2007) Cannabis use and self-reported collisions in a representative sample of adult drivers. J Saf Res 38(6):669-674.

82. Buckley L, Sheehan M (2007) Does an ecological model explain self-report motorcycle use and injuries among early adolescents? In: Australasian road safety research policing education conference, 2007, Melbourne, Victoria, Australia, p 13.

83. Wundersitz LN (2008) Can personality characteristics predict the crash involvement of young drivers? In: Australasian road safety research policing education conference, 2008, Adelaide, South Australia, Australia, p 10.

84. Tronsmoen $T$ (2010) Associations between driver training, determinants of risky driving behaviour and crash involvement. Saf Sci 48(1):35-45.

85. Palk G, Freeman J, Kee AG, Steinhardt D, Davey J (2011) The prevalence and characteristics of self-reported dangerous driving behaviours among a young cohort. Transport Res F: Traffic Psychol Behav 14(2):147-154.

86. Sumer N (2011) Cognitive and Psychomotor Correlates of Hazard Perception Ability and Risky Driving. In: Driving assessment 2011: 6th international driving symposium on human factors in driver assessment, training and vehicle design, olympic valley - lake Tahoe CA, pp 211-217

87. Shaw L, Poulos R, Hatfield J, Rissel C (2012) Exploring an application of the safe system approach to a set of self-reported cycling crashes. In: 2012 ACRS national conference, The Menzie, Sydney, Australia, pp 1-14.

88. Dingli K, Buckley L, Reveruzzi B, Chapman R, Sheehan M.Reducing road related injuries for young adolescents: an investigation of truancy as a risk factor. In: Australiasian road safety research, policing \& education workshop, Wellington, New Zealand, pp 1-9.

89. Qu W, Ge Y, Jiang C, Du F, Zhang K (2014) The dula dangerous driving index in China: an investigation of reliability and validity. Accid Anal Prev 64:62-68.
90. Armstrong K, Obst P, Livingstone K, Haworth N (2011) Investigation of differences in crash characteristics between males and females involved in fatigue-related crashes or close-call events. In: Transportation research board conference proceedings, women's issues in transportation, vol 2, pp 26-33

91. Hassan HM, Abdel-Aty MA (2013) Exploring the safety implications of young drivers' behavior, attitudes and perceptions. Accid Anal Prev 50:361-370 https://doi.org/10.1016/j.aap.2012.05.003

92. Bon de Sousa T, Santos C, Mateus C, Areal A, Trigoso J, Nunes C (2016) Road traffic accidents and self-reported Portuguese car driver's attitudes, behaviors, and opinions: are they related? Traffic Inj Prev 17(7):705-711. https://doi.org/10.1080/15389588.2016.1150591

93. Chai J, Qu W, Sun X, Zhang K, Ge Y (2016) Negativity bias in dangerous drivers. PLoS One 11(1).https://doi.org/10.1371/journal.pone.0147083

94. De Gruyter C, Truong LT, Nguyen HTT (2017) Who's calling? Social networks and mobile phone use among motorcyclists. Accid Anal Prev 103:143-147. https://doi.org/10.1016/j.aap.2017.04.010

95. Gliklich E, Guo R, Bergmark RW (2016) Texting while driving: a study of 1211 U.S. adults with the distracted driving survey. Prev Med Rep 4:486-489. https://doi.org/10.1016/j.pmedr.2016.09.003

96. Isler RB, Newland SA (2017) Life satisfaction, well-being and safe driving behaviour in undergraduate psychology students. Transport Res F: Traffic Psychol Behav 47:143-154.

97. Sullman MJM, Stephens AN, Pajo K (2017) Transport company safety climate - the impact on truck driver behavior and crash involvement. Traffic Inj Prev 18(3):306-311. https://doi.org/10.1080/15389588.2016.1199865

98. Vanparijs J, Int Panis L, Meeusen R, de Geus B (2016) Characteristics of bicycle crashes in an adolescent population in Flanders (Belgium). Accid Anal Prev 97:103-110. https://doi.org/10.1016/j.aap.2016.08.018

99. Wickens CM, Mann RE, lalomiteanu AR, Rehm J, Fischer B, Stoduto G, Callaghan RC, Sayer G, Brands B (2017) The impact of medical and nonmedical prescription opioid use on motor vehicle collision risk. Transport Res F: Traffic Psychol Behav 47:155-162.

100. Wickens CM, Mann RE, lalomiteanu AR, Stoduto G (2016) Do driver anger and aggression contribute to the odds of a crash? A population-level analysis. Transp Res Part F 42(Part 2):389-399.

101. Wickens CM, Smart RG, Vingilis E, lalomiteanu AR, Stoduto G, Mann RE (2017) Street racing among the Ontario adult population: prevalence and association with collision risk. Accid Anal Prev 103:85-91.

102. Zhang X, Yang Y, Chen Y, Yao H, Wu M, Cui M, Li Y, Hu J, Zhang C, Li Z, Stallones $L$, Xiang $H$ (2017) Road traffic crashes among farm vehicle drivers in southern China: a cross-sectional survey. Traffic Inj Prev 18(1):83-87. https://doi.org/10.1080/15389588.2016.1190840

103. Johnson B (2006) Modelling the collision risk of London's motorcyclists. In: Behavioural research in road safety, 16th seminar, pp 133-157.

104. Antonopoulos CN, Germeni E, Bacopoulou F, Kalampoki V, Maltezos S, Skalkidis I, Daskalopoulou S, Negri E, Petridou E (2011) Assessing the impact of risk-taking behavior on road crash involvement among university students residing in two Mediterranean countries. Saf Sci 49(6):933-938. https://doi.org/10.1016/j.ssci.2011.03.013

105. de Rome L, Boufous S, Georgeson T, Senserrick T, Ivers R (2014) Cyclists' clothing and reduced risk of injury in crashes. Accid Anal Prev 73:392-398. https://doi.org/10.1016/j.aap.2014.09.022

106. Gras M-E, Font-Mayolas S, Planes M, Sullman MJM (2014) The impact of the penalty point system on the behaviour of young drivers and passengers in Spain. Saf Sci 70:270-275. https://doi.org/10.1016/j.ssci.2014.06.014

107. Hollingworth MA, Harper AJL, Hamer M (2015) Risk factors for cycling accident related injury: the UK cycling for health survey. J Transp Health 2(2):189-194. https://doi.org/10.1016/j.jth.2015.01.001

108. Isho T, Tashiro H, Usuda S (2015) Accelerometry-based gait characteristics evaluated using a smartphone and their association with fall risk in people with chronic stroke. J Stroke Cerebrovasc Dis 24(6):1305-1311. https://doi. org/10.1016/j.jstrokecerebrovasdis.2015.02.004

109. Lucidi F, Giannini AM, Sgalla R, Mallia L, Devoto A, Reichmann S (2010) Young novice driver subtypes: relationship to driving violations, errors and lapses. Accid Anal Prev 42(6):1689-1696. https://doi.org/10.1016/j. aap. 2010.04 .008

110. Lucidi F, Mallia L, Lazuras L, Violani C (2014) Personality and attitudes as predictors of risky driving among older drivers. Accid Anal Prev 72:318-324. https://doi.org/10.1016/j.aap.2014.07.022

111. Poulos RG, Hatfield J, Rissel C, Flack LK, Murphy S, Grzebieta R, McIntosh AS (2015) An exposure based study of crash and injury rates in a cohort of 
transport and recreational cyclists in New South Wales, Australia. Accid Anal Prev 78:29-38. https://doi.org/10.1016/j.aap.2015.02.009

112. Richer I, Bergeron J (2009) Driving under the influence of cannabis: links with dangerous driving, psychological predictors, and accident involvement. Accid Anal Prev 41(2):299-307. https://doi.org/10.1016/j.aap.2008.12.004

113. Salminen S, Vartia M, Giorgiani T (2009) Occupational injuries of immigrant and Finnish bus drivers. J Saf Res 40(3):203-205. https://doi.org/10.1016/j.jsr. 2009.03.004

114. Scott-Parker B, Watson B, King MJ, Hyde MK (2012) Confirmatory factor analysis of the Behaviour of Young Novice Drivers Scale (BYNDS). Accid Anal Prev 49:385-391. https://doi.org/10.1016/j.aap.2012.02.021

115. Aduen PA, Kofler MJ, Cox DJ, Sarver DE, Lunsford E (2015) Motor vehicle driving in high incidence psychiatric disability: comparison of drivers with ADHD, depression, and no known psychopathology. J Psychiatr Res 64:59-66. https://doi.org/10.1016/j.jpsychires.2015.03.009

116. Álvarez FJ, Gómez-Talegón T, Marcos A (2010) Accident rates for drugdependent patients in treatment for substance dependence: a pilot trial. Traffic Inj Prev 11(5):460-465. https://doi.org/10.1080/15389588. 2010.492844

117. Magalhães AF, Lopes CM, Koifman RJ, Muniz PT (2011) Prevalence of selfreported traffic accidents in Rio Branco, Northern Brazil. Rev Saude Publica 45(4):738-744. https://doi.org/10.1590/50034-89102011005000031

118. Mann RE, Stoduto G, Butters J, lalomiteanu A, Boase P, Asbridge M, Chipman M, Wickens CM (2010) Age group differences in collision risk. J Saf Res 41(5):445-449. https://doi.org/10.1016/j.jsr.2010.08.004

119. Mann RE, Stoduto G, lalomiteanu A, Asbridge M, Smart RG, Wickens CM (2010) Self-reported collision risk associated with cannabis use and driving after cannabis use among Ontario adults. Traffic Inj Prev 11(2):115-122. https://doi.org/10.1080/15389580903536704

120. Powell NB, Schechtman KB, Riley RW, Guilleminault C, Chiang RPY, Weaver EM (2007) Sleepy driver near-misses may predict accident risks. Sleep 30(3):331-342.

121. Ross LA, Dodson JE, Edwards JD, Ackerman ML, Ball K (2012) Self-rated driving and driving safety in older adults. Accid Anal Prev 48:523-527. https://doi.org/10.1016/j.aap.2012.02.015

122. Warner HW, Ozkan T, Lajunen T, Tzamalouka G (2011) Cross-cultural comparison of drivers' tendency to commit different aberrant driving behaviours. Transport Res F: Traffic Psychol Behav 14(5):390-399.

123. Vingilis E, Seeley J, Wiesenthal D, Mann R, Vingilis-Jaremko L, Vanlaar W, Leal N (2013) Street racing and stunt driving in Ontario, Canada: results of a web-based survey of car and racing enthusiasts. Transport Res F: Traffic Psychol Behav 21:30-42.

124. Mamo WG, Newnam S, Tulu GS (2014) Investigating the individual and organisational predictors of work-related driving crash involvement in Ethiopia. Transport Res F: Traffic Psychol Behav 23:156-164.

125. Bongers S, Slottje P, Portengen L, Kromhout H (2016) Exposure to static magnetic fields and risk of accidents among a cohort of workers from a medical imaging device manufacturing facility. Magn Reson Med 75(5): 2165-2174. https://doi.org/10.1002/mrm.25768

126. Vingilis E, Mann RE, Erickson P, Toplak M, Kolla NJ, Seeley J, Jain U (2014) Attention deficit hyperactivity disorder, other mental health problems, substance use, and driving: examination of a population-based, representative Canadian sample. Traffic Inj Prev 15:S1-S9.

127. Henriksson P, Levin L, Willstrand T, Peters B (2014) Challenging situations, self-reported driving habits and capacity among older drivers (70+) in Sweden: a questionnaire study. Swedish National Road and Transport Research Institute (VTI).

128. Thiese MS, Ott U, Robbins R, Effiong A, Murtaugh M, Lemke MR, DeckowSchaefer G, Kapellusch J, Wood E, Passey D, Hartenbaum N, Garg A, Hegmann KT (2015) Factors associated with truck crashes in a large cross section of commercial motor vehicle drivers. J Occup Environ Med 57(10): 1098-1106. https://doi.org/10.1097/JOM.0000000000000503

129. Poulos RG, Hatfield J, Rissel C, Flack LK, Murphy S, Grzebieta R, Mclntosh AS (2015) Characteristics, cycling patterns, and crash and injury experiences at baseline of a cohort of transport and recreational cyclists in New South Wales, Australia. Accid Anal Prev 78:155-164. https://doi.org/10.1016/j.aap.2015.02.008

130. Campbell BT, Borrup K, Derbyshire M, Rogers S, Lapidus G (2016) Efficacy of driving simulator training for novice teen drivers. Conn Med 80(5):291-296

131. Ross P, Ponsford JL, Di Stefano M, Charlton J, Spitz G (2016) On the road again after traumatic brain injury: driver safety and behaviour following onroad assessment and rehabilitation. Disabil Rehabil 38(10):994-1005. https:// doi.org/10.3109/09638288.2015.1074293
132. af Wåhlberg AE (2011) The accident-exposure association: self-reported versus recorded collisions. J Saf Res 42(2):143-146. https://doi.org/10.1016/j. jsr.2011.01.007

133. Cheng AS-K, Ng TC-K (2010) Development of a Chinese motorcycle rider driving violation questionnaire. Accid Anal Prev 42(4):1250-1256. https://doi. org/10.1016/.j.aap.2010.01.018

134. Anstey KJ, Wood J, Caldwell H, Kerr G, Lord SR (2009) Comparison of selfreported crashes, state crash records and an on-road driving assessment in a population-based sample of drivers aged 69-95 years. Traffic Inj Prev 10(1): 84-90. https://doi.org/10.1080/15389580802486399

135. Hoggarth P, Jones R, Innes C, Dalrymple-Alford J (2009) Driving Assessment and Subsequent Driving Outcome: A Prospective Study of Safe and Unsafe Healthy Driver Groups. In: Driving Assessment 2009: 5th International Driving Symposium on Human Factors in Driver Assessment, Training and Vehicle Design, Big Sky MT, pp 433-439.

136. Tin Tin S, Woodward A, Ameratunga S (2013) Completeness and accuracy of crash outcome data in a cohort of cyclists: a validation study. BMC Public Health 13(1). https://doi.org/10.1186/1471-2458-13-420

137. Medury A, Grembek O, Loukaitou-Sideris A, Shafizadeh K (2017) Investigating the underreporting of pedestrian and bicycle crashes in and around university campuses - a crowdsourcing approach. Accid Anal Prev. https://doi.org/10.1016/j.aap.2017.08.014

138. Singletary BA, Do AN, Donnelly JP, Huisingh C, Mefford MT, Modi R, Mondesir FL, Ye Y, Owsley C, McGwin G (2017) Self-reported vs state-recorded motor vehicle collisions among older community dwelling individuals. Accid Anal Prev 101:22-27. https://doi.org/10.1016/j.aap.2017.01.021

139. Winters M, Branion-Calles M (2017) Cycling safety: quantifying the under reporting of cycling incidents in Vancouver, British Columbia. J Transp Health. https://doi.org/10.1016/j.jth.2017.02.010

140. de Rome L, Boufous S, Georgeson T, Senserrick T, Richardson D, Ivers R (2014) Bicycle crashes in different riding environments in the Australian capital territory. Traffic Inj Prev 15(1):81-88. https://doi.org/10.1080/ 15389588.2013.781591

141. Mallia L, Lazuras L, Violani C, Lucidi F (2015) Crash risk and aberrant driving behaviors among bus drivers: the role of personality and attitudes towards traffic safety. Accid Anal Prev 79:145-151. https://doi.org/10.1016/j.aap.2015.03.034

142. Mann RE, Zhao J, Stoduto G, Adlaf EM, Smart RG, Donovan JE (2007) Road rage and collision involvement. Am J Health Behav 31(4):384-391.

143. Valencia-Martin JL, Galan I, Rodriguez-Artalejo F (2008) The joint association of average volume of alcohol and binge drinking with hazardous driving behaviour and traffic crashes. Addiction 103(5):749-757.

144. af Wåhlberg AE (2011) Memory effects in self-reports of road traffic crashes. In: International conference on driver behaviour and training, 5th, Paris, France, pp 283-288.

145. Tran TT, Adams-Bedford J, Yiengprugsawan V, Seubsman SA, Sleigh A (2016) Psychological distress following injury in a large cohort of Thai adults. PLoS One 11(10). https://doi.org/10.1371/journal.pone.0164767

146. Watson A, Watson B, Vallmuur K (2015) Estimating under-reporting of road crash injuries to police using multiple linked data collections. Accid Anal Prev 83(Supplement C):18-25. https://doi.org/10.1016/j.aap.2015.06.011

147. Maycock G, Lockwood CR, Lester JF (1991) The accident liability of car drivers (report no 315). Transport and road research laboratory, department of transport, Crowthorne, Berkshire, RG11 6AU.

148. InDeV (2018) In-depth understanding of accident causation for vulnerable road users. http://www.indev-project.eu/InDeV/EN/Home/home_node.html

149. Rosman DL (1996) The feasibility of linking hospital and police road crash casualty records without names. Accid Anal Prev 28(2):271-274. https://doi. org/10.1016/0001-4575(95)00058-5 